\title{
Carbon dioxide atmospheric vertical profiles retrieved from space observation using ACE-FTS solar occultation instrument
}

\author{
P. Y. Foucher ${ }^{1,2}$, A. Chédin ${ }^{1}$, R. Armante ${ }^{1}$, C. Boone ${ }^{3}$, C. Crevoisier ${ }^{1}$, and P. Bernath ${ }^{3,4}$ \\ ${ }^{1}$ Laboratoire de Météorologie Dynamique/Institut Pierre Simon Laplace, Ecole Polytechnique, 91128 Palaiseau, France \\ ${ }^{2}$ Onera - The French Aerospace Lab, Centre Midi-Pyrénées, 31055 Toulouse Cedex 4, France \\ ${ }^{3}$ Department of Chemistry, University of Waterloo, Ontario, N2L3G1, Canada \\ ${ }^{4}$ Department of Chemistry, University of York, Heslington, York, YO105DD, UK
}

Received: 9 August 2010 - Published in Atmos. Chem. Phys. Discuss.: 5 November 2010

Revised: 25 February 2011 - Accepted: 8 March 2011 - Published: 16 March 2011

\begin{abstract}
Major limitations of our present knowledge of the global distribution of $\mathrm{CO}_{2}$ in the atmosphere are the uncertainty in atmospheric transport and the sparseness of in situ concentration measurements. Limb viewing spaceborne sounders such as the Atmospheric Chemistry Experiment Fourier transform spectrometer (ACE-FTS) offer a vertical resolution of a few kilometres for profiles, which is much better than currently flying or planned nadir sounding instruments can achieve. After having demonstrated the feasibility of obtaining $\mathrm{CO}_{2}$ vertical profiles in the $5-25 \mathrm{~km}$ altitude range with an accuracy of about $2 \mathrm{ppm}$ in a previous study, we present here the results of five years of ACE-FTS observations in terms of monthly mean profiles of $\mathrm{CO}_{2}$ averaged over $10^{\circ}$ latitude bands for northern mid-latitudes. These results are compared with in-situ aircraft measurements and with simulations from two different air transport models. Key features of the measured altitude distribution of $\mathrm{CO}_{2}$ are shown to be accurately reproduced by the ACE-FTS retrievals: variation in altitude of the seasonal cycle amplitude and extrema, seasonal change of the vertical gradient, and mean growth rate. We show that small but significant differences from model simulations could result from an over estimation of the model circulation strength during the northern hemisphere spring. Coupled with column measurements from a nadir viewing instrument, it is expected that occultation measurements will bring useful constraints to the surface carbon flux determination.
\end{abstract}

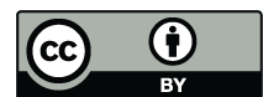

Correspondence to: P. Y. Foucher (pierre-yves.foucher@1md.polytechnique.fr)

\section{Introduction}

Determining the spatial and temporal structure of surface carbon fluxes has become a major scientific goal during the last decade. In the so-called "inverse" approach, observed atmospheric concentration gradients are used to disentangle surface fluxes, given some description of atmospheric transport. Major limitations of the inverse approach are the sparseness of atmospheric $\mathrm{CO}_{2}$ concentration measurements, often compensated for by introducing questionable constraining conditions, and, more significantly, the uncertainties in atmospheric transport. Since $\mathrm{CO}_{2}$ is inert in the lower atmosphere, its long-term trend and pronounced seasonal cycle propagate from the surface, and the difference between atmospheric and surface mixing ratios is determined by the processes that transport surface air throughout the atmosphere, including advection, convection and eddy mixing (Shia et al., 2006). Because it takes several months to transport surface air to the lower stratosphere, the $\mathrm{CO}_{2}$ mixing ratio is lower and the seasonal cycle is different there as compared to the troposphere (Plumb and Ko, 1992; Plumb, 1996; Shia et al., 2006). Bönisch et al. (2008) evaluated transport in threedimensional chemical transport models in the upper troposphere and lower stratosphere by using observed distributions of $\mathrm{CO}_{2}$ and $\mathrm{SF}_{6}$. They show that although all models are able to capture the general features in tracer distributions including the vertical and horizontal propagation of the $\mathrm{CO}_{2}$ seasonal cycle, important problems remain such as: (i) a too strong Brewer-Dobson circulation (with air rising across the tropical tropopause, moving poleward, and sinking to the extratropical troposphere) causing an overestimate of the tracer concentration in the lower most stratosphere (LMS) during

Published by Copernicus Publications on behalf of the European Geosciences Union. 
winter and spring and, (ii) a too strong tropical isolation leading to an underestimate of the tracers in the LMS during winter. Moreover, all models tested suffer to some extent from diffusion and/or too strong mixing across the tropopause. In addition, the models show too weak vertical upward transport into the upper troposphere during the boreal summer.

In recent years it has become possible to measure atmospheric $\mathrm{CO}_{2}$ from space observations by the nadir-viewing thermal infrared vertical sounders such as TIROS-N Operational Vertical Sounder (TOVS) (Chédin et al., 2002, 2003a), Atmospheric Infrared Sounder (AIRS), Infrared Atmospheric Sounder Interferometer (IASI) (Chédin et al., 2003b; Crevoisier et al., 2004, 2009) and Tropospheric Emission Spectrometer (TES) instrument (Kulawik et al., 2010), or in the near infrared by SCIAMACHY (Buchwitz et al., 2005) and Greenhouse gases Observing SATellite (GOSAT) (Kuze et al., 2009). However, the satellite data products are all vertically integrated concentrations rather than the profile measurements that are essential for a comprehensive understanding of distribution mechanisms of $\mathrm{CO}_{2}$. The difference between the column-averaged $\mathrm{CO}_{2}$ mixing ratio and the surface value varies from 2 to $10 \mathrm{ppm}$ depending on location and time of year (Olsen and Randerson, 2004). The upper troposphere can contribute significantly to this difference because this portion of the column constitutes approximately $20 \%$ of the column air mass and the $\mathrm{CO}_{2}$ mixing ratios in this region can differ by 5 ppm or more from the $\mathrm{CO}_{2}$ mixing ratios at the surface (Anderson et al., 1996; Matsueda et al., 2002; Shia et al., 2006). With limb sounders that observe the atmosphere along tangential optical paths, the vertical resolution of the measured vertical profiles is of the order of a few kilometres, much better than can be achieved with nadir sounding instruments. The Atmospheric Chemistry Experiment Fourier transform spectrometer (ACE-FTS), launched in August 2003 on board SCISAT, is a limb sounder that records solar occultation measurements (up to 30 occultations each day) with coverage between approximately $85^{\circ} \mathrm{N}$ and $85^{\circ} \mathrm{S}$ (Bernath et al., 2005), with more observations at high latitudes than over the tropics (Bernath et al., 2006). The ACE-FTS has high spectral resolution $\left(0.02 \mathrm{~cm}^{-1}\right)$ and the signal-to-noise ratio of ACE-FTS spectra is higher than $300: 1$ over a large portion $\left(1000-3000 \mathrm{~cm}^{-1}\right)$ of the spectral range covered $\left(750-4400 \mathrm{~cm}^{-1}\right)$. Recently, Foucher et al. (2009) and Foucher (2009) have shown that the ACE-FTS instrument is able to provide $\mathrm{CO}_{2}$ vertical profiles in the 5$25 \mathrm{~km}$ altitude range with an estimated $\mathrm{CO}_{2}$ total error characterized by a bias of about $\pm 1 \mathrm{ppm}$ and a standard deviation of about 2 ppm after averaging over 20 spatially and temporally consistent retrieved profiles. Rinsland et al. (2010), using ACE-FTS and a method similar to that of Foucher et al. (2009), have retrieved average dry air $\mathrm{CO}_{2}$ mole fractions in the layer $7-10 \mathrm{~km}$ but did not extend their study to the retrieval of profiles. Beagley et al. (2010), again using ACE-FTS, have retrieved $\mathrm{CO}_{2}$ profiles in the mesosphere and lower thermosphere where the problem of pointing knowl- edge uncertainties is not a concern. Our analysis is organised as follows. We first summarize the main features of the method developed to retrieve $\mathrm{CO}_{2}$ profiles and describe how ACE-FTS occultations are selected (Sect. 2) and the limits of their spatial and temporal coverage. ACE-retrieved monthly mean $\mathrm{CO}_{2}$ vertical profiles averaged over the latitude bands $40^{\circ} \mathrm{N}-60^{\circ} \mathrm{N}$ and $50^{\circ} \mathrm{N}-0^{\circ} \mathrm{N}$ and covering the 2004-2008 time period are then presented and compared (vertical gradients, seasonal cycles at various altitudes, growth rates) with aircraft in-situ measurements (Sect. 3) and with simulations from two different air transport models (Sect. 4). Section 5 presents our conclusions.

\section{Method and ACE-FTS data}

The methodology used to determine $\mathrm{CO}_{2}$ profiles from ACEFTS observations has been described in detail in Foucher et al. (2009), hereafter referred to as Fal2009, and Foucher (2009). The retrieval process has two main steps: pointing parameter estimation (tangent heights, pressure and temperature profiles) and $\mathrm{CO}_{2}$ vertical profile estimation. Both steps use a similar constrained least-squares retrieval method. The target variable is a vector containing tangent heights and a temperature profile in the first step or a $\mathrm{CO}_{2}$ concentration vertical profile in the second step.

\subsection{ACE-FTS pointing knowledge}

Interpreting limb viewing observations in terms of atmospheric variables requires accurate knowledge of instrument pointing parameters (tangent heights) and pressure/temperature ("pT") vertical profiles. Reactive trace gases are the usual target species of limb-viewing instruments, so pointing parameters are simultaneously retrieved with pT by the analysis of properly selected $\mathrm{CO}_{2}$ lines under the assumption (questionable, in certain cases) of a weak variation of its atmospheric concentration around a given a priori value. As carbon dioxide is here the target species, a critical step in this research has therefore been to develop a method of obtaining pT profiles and tangent heights independent of any a priori $\mathrm{CO}_{2}$ knowledge. A new approach based on the $\mathrm{N}_{2}$ collision-induced continuum absorption near $4.3 \mu \mathrm{m}$ was presented in Fal2009 together with a new parametric $\mathrm{N}_{2}$ continuum absorption model derived from Lafferty et al. (1996) laboratory measurements. The high sensitivity of $\mathrm{N}_{2}$ continuum absorption to tangent height affords a precision of better than $50 \mathrm{~m}$ in the tangent height retrieval. Figure 1 shows $\mathrm{N}_{2}$ continuum transmittance sensitivity to tangent height in the $2400-2600 \mathrm{~cm}^{-1}$ spectral range. As explained in Fal2009, five optimized micro-windows were selected in the 2400 to $2500 \mathrm{~cm}^{-1}$ wave number range in order to cover the $5-25 \mathrm{~km}$ altitude range. Here, a new micro-window near $2430 \mathrm{~cm}^{-1}$ has been added to increase sensitivity to highest altitudes. In an iterative process using 


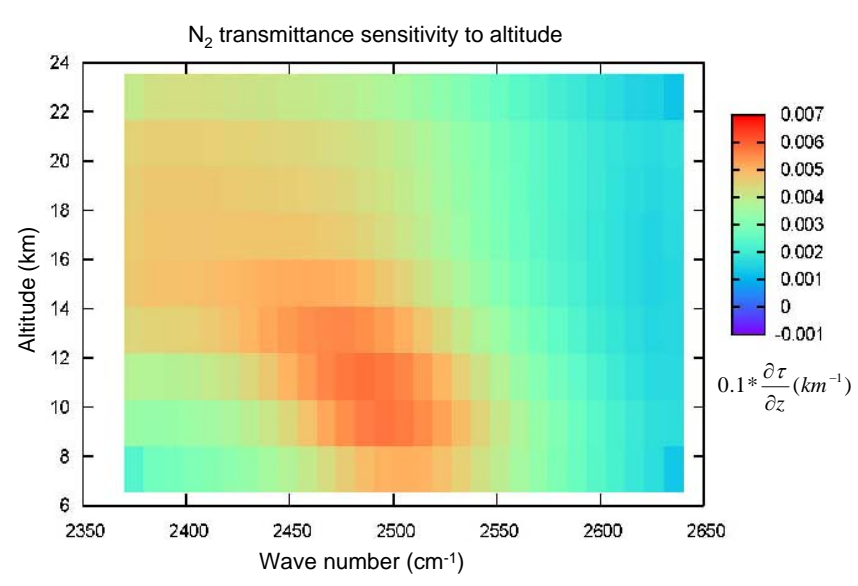

Fig. 1. Transmittance sensitivity to tangent height in the $\mathrm{N}_{2}$ collision-induced absorption $\left(2370-2640 \mathrm{~cm}^{-1}\right)$ spectral range. The color bar values represent the transmission variation due to a $100 \mathrm{~m}$ tangent height change.

hydrostatic equilibrium we obtain ACE-FTS tangent heights independent of a priori $\mathrm{CO}_{2}$ data with a high precision $(50 \mathrm{~m}$ standard deviation). Finally, empirical corrections are added to these tangent heights to account for problems in the transmission model which does not include effects of $\mathrm{N}_{2}-\mathrm{H}_{2} \mathrm{O}$ collisions, which are still not accurately known. In addition, although we included the latest developments in the modelling of line wings based on Niro et al. (2004), there might still be uncertainties near $2400 \mathrm{~cm}^{-1}$. These empirical corrections have been estimated based on the analysis of the mean difference between ACE v2.2 tangent heights (Boone et al., 2005) and tangent heights retrieved from the $\mathrm{N}_{2}$ continuum, based on averages over the entire 2004-2008 time period. This mean bias depends on the altitude and varies from $-2.5 \%$ at lowest altitude to $+2 \%$ at $20 \mathrm{~km}$. This correction is applied to all occultations and is described in more detail in Foucher et al. (2009). Using a method similar to that described in Foucher (2009), Rinsland et al. (2010) find ACEretrieved $\mathrm{CO}_{2}$ mean tropospheric concentration for the layer $7-10 \mathrm{~km}$ around $405-420 \mathrm{ppm}$, too high by about $30 \mathrm{ppm}$. This large bias is likely due to the use of an uncorrected $\mathrm{N}_{2}$ continuum absorption.

\subsection{Selection of ACE-FTS occultations}

A high inclination $\left(74^{\circ}\right)$, circular, low Earth orbit $(650 \mathrm{~km})$ gives ACE coverage of tropical, mid-latitude and polar regions. The ACE orbit was selected so that the coverage repeats annually in latitude (Bernath et al., 2006) and is optimized for high latitude coverage in both hemispheres. Observations are available since early 2004. To be selected for the $\mathrm{CO}_{2}$ retrieval process, an ACE-FTS occultation must fulfill two criteria.
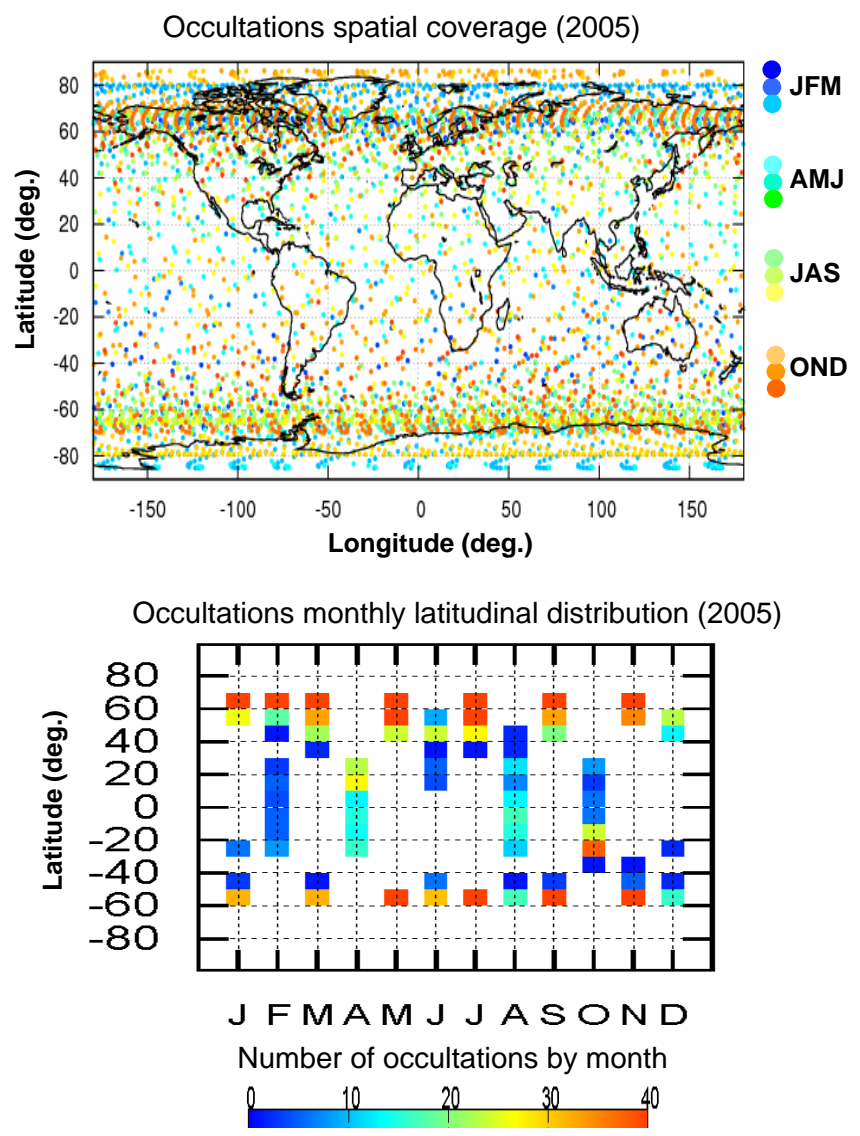

Fig. 2. Locations of ACE-FTS occultations available in 2005 per month (color scale) (top); monthly distribution of the number of occultations per $10^{\circ}$ latitude band (bottom).

First, the occultation must be declared "clear" after having passed a series of tests aimed at detecting the presence of clouds along the optical path. These tests are based on comparisons between clear-sky simulated and measured transmittances. Using a quasi transparent window near $970 \mathrm{~cm}^{-1}(10.3 \mu \mathrm{m})$, an occultation is rejected if the measured transmittance is lower than a fixed value corresponding to the occultation tangent height, these threshold values being determined from simulations. Similar "static" tests are carried out for $\mathrm{N}_{2}$ micro-windows. Then, "dynamic" tests are carried out consisting of comparing changes in transmittance from one measurement to the next. If the difference is larger than what can be expected from simulations, the occultation is rejected. These dynamic tests use the $\mathrm{N}_{2}$ micro-windows.

Second, the lowest measured tangent height must be less than $12 \mathrm{~km}$ as ACE occultations beginning at tangent altitudes higher than $12 \mathrm{~km}$ are often characterized by a high probability of instrumental or meteorological anomalies such as clouds. Figure 2 (top) shows the locations of the occultations finally selected for each month of the year 2005 and the monthly distribution of the number of occultations available for $10^{\circ}$ latitude bands from $60^{\circ} \mathrm{N}$ to $60^{\circ} \mathrm{S}$ for the year 2005 . 


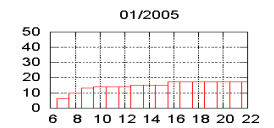
$02 / 2005$

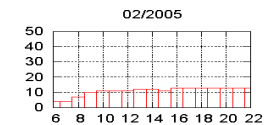

$03 / 2005$
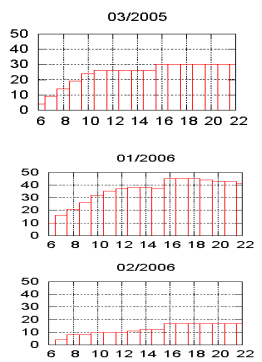

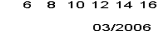
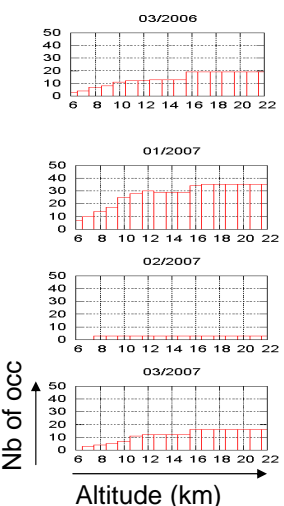

Altitude $(\mathrm{km})$

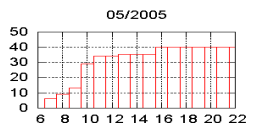

$06 / 2005$

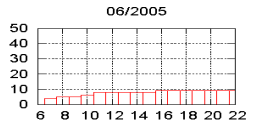

$07 / 2005$

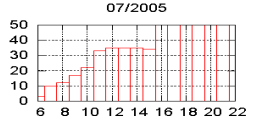

$05 / 200$

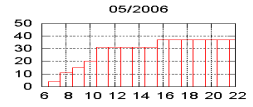

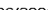

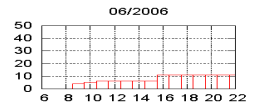

(0)
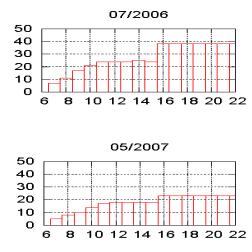

$06 / 200$
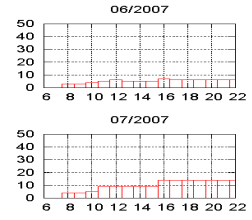

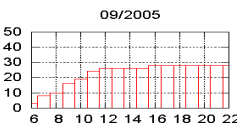

$11 / 2005$

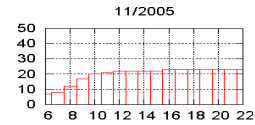

$12 / 200$
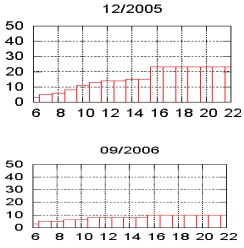

$11 / 2000$

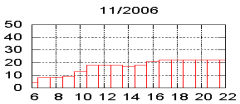

120000
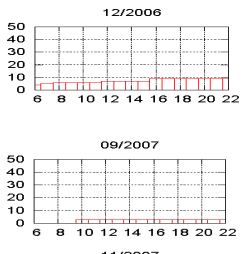

$11 / 2007$

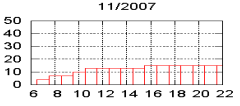

$12 / 2007$

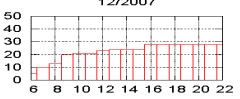

Fig. 3. Number of ACE-FTS occultations (y-axis) available for the $50^{\circ} \mathrm{N}-60^{\circ} \mathrm{N}$ latitude band for nine months of the years 2005 to 2007 (April, August and September are not covered for this latitude band) and for each altitude (x-axis, unit: $\mathrm{km}$ ).

The prevalence of high latitudes is clearly seen in Fig. 2 although some lower latitudes also have a considerable number of occultations as shown in Fig. 2 (bottom). The present analysis of the first ACE-retrieved $\mathrm{CO}_{2}$ profiles focuses on the $50^{\circ} \mathrm{N}-60^{\circ} \mathrm{N}$ latitude band which is seen to be the richest band for occultations over non polar regions. Figure 3 shows the number of occultations available per month ( $y$ axis), for each altitude in the range 6-22 km (x-axis), in the $50^{\circ} \mathrm{N}-60^{\circ} \mathrm{N}$ latitude band and for each year from 2005 to 2007. Available occultations presented in Fig. 2 correspond to about $50 \%$ of the total number of ACE occultations. This figure shows a substantial variability in altitude and month as well as in time. As already seen in Fig. 2 for this latitude band, some months are not covered at all (April, August, and October). However, for the nine other months, results must be interpreted carefully when the number of occultations available is significantly less than 20 . This is the case below $8 \mathrm{~km}$ most of the time. This is also the case for February, June and September in 2007 at all altitudes for this latitude band and for other year/months. The year 2005 shows the largest number of months with more than 20 occultations

available for a relatively large number of altitudes (about 6 months); 2006 and 2007 only show 4 such months.

\section{3 $\mathrm{CO}_{2}$ profile retrieval}

The method used to determine $\mathrm{CO}_{2}$ profiles from ACE-FTS observations has been described in Fal2009. The $\mathrm{CO}_{2}$ microwindow optimized selection is composed of two sets, one dedicated to the $5-15 \mathrm{~km}$ altitude range using the ${ }^{18} \mathrm{OC}^{16} \mathrm{O}$ isotopologue and the other dedicated to the $10-25 \mathrm{~km}$ altitude range using the main isotopologue ${ }^{12} \mathrm{C}^{16} \mathrm{O}_{2}$. In each case, about 15 microwindows with a spectral width of 0.2 to $0.5 \mathrm{~cm}^{-1}$ (located around 1900, 2600 and $3000 \mathrm{~cm}^{-1}$ ) have been selected from a larger set of more than $80 \mathrm{mi}-$ crowindows given in Foucher (2009). As shown in this reference, increasing the number of microwindows used for the retrieval decreases the instrumental noise error but, at the same time, may increase errors due to uncertainties in temperature and other interfering species. We have shown that the mean error due to all sources of uncertainties decreases from $10 \mathrm{ppm}$ using only one micro-window to $3 \mathrm{ppm}$ using 15 micro-windows. An altitude dependent regularization matrix has been used based on a 1st order Tikhonov regularization matrix (Tikhonov, 1963) weighted by a priori knowledge of $\mathrm{CO}_{2}$ variance from the MOZART chemistry and transport model (Horowitz et al., 2003). The forward solution of the radiative transfer equation is provided by the $4 \mathrm{~A} / \mathrm{OP}-$ limb Radiative Transfer Model. 4A (for Automatized Atmospheric Absorption Atlas) is a fast and accurate line-by-line radiative transfer model (Scott and Chédin, 1981) developed and maintained at Laboratoire de Météorologie Dynamique (LMD; see http://ara.lmd.polytechnique.fr) and was made operational (OP) in cooperation with the French company Noveltis (see http://www.noveltis.fr/4AOP/ for a description of the $4 \mathrm{~A} / \mathrm{OP}$ version).

Figure $4 \mathrm{a}$ shows results from realistic simulations of retrieved $\mathrm{CO}_{2}$ mixing ratio profiles averaged over 20 occultations. In the first case (blue curves), all uncertainties (temperature, instrument, interfering species, etc.) are considered as spectrally independent and translated into an equivalent Gaussian random noise. This equivalent noise corresponds to around 4 times the signal to noise ratio in the analyzed transmittance spectra, that is to say $1 \%$. In the second case (red curves), uncertainties are introduced directly in the description of the atmosphere of each retrieval, temperature ( $2 \mathrm{~K}$ standard deviation) and interfering species concentration (10\% standard deviation), prior to simulating "observed" transmittances. In the second case, more realistic, the mean retrieval bias after averaging over 20 occultations is around $1 \mathrm{ppm}$ with a standard deviation of about 3-4 ppm, and decreases for increasing altitudes (see Fal2009). Results from a detailed analysis of the retrieval process presented in Fal2009 have demonstrated a mean vertical resolution of about $2.5 \mathrm{~km}$. This is summarized on Fig. $4 \mathrm{~b}$ which shows examples of averaging kernels for levels at $6,8,10,12$, and 

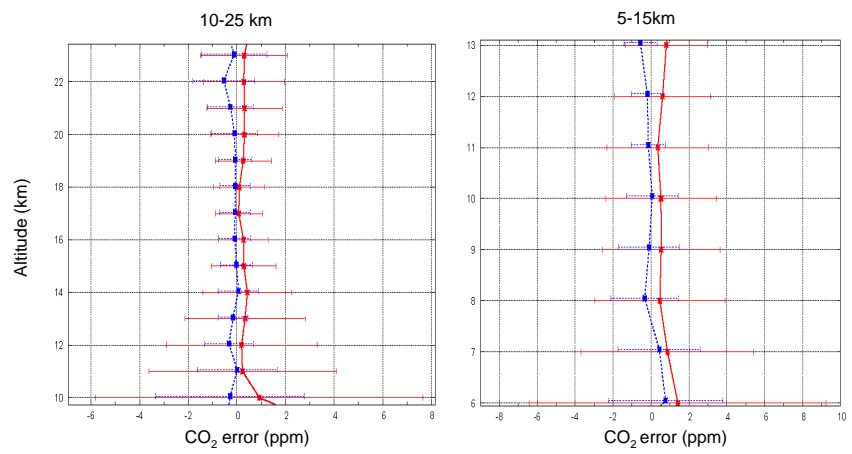

Fig. 4a. Results of synthetic retrievals of the $\mathrm{CO}_{2}$ mixing ratio difference (in ppm) between the true profile and the retrieved profile (average over 20 occultations). Blue curve: all the uncertainties are considered as Gaussian random noise added to the "observations"; red curve: realistic temperature and species $\left(\mathrm{N}_{2} \mathrm{O}, \mathrm{O}_{3}\right.$, etc.) uncertainties are introduced in the atmospheric model; horizontal bars are one standard deviation.

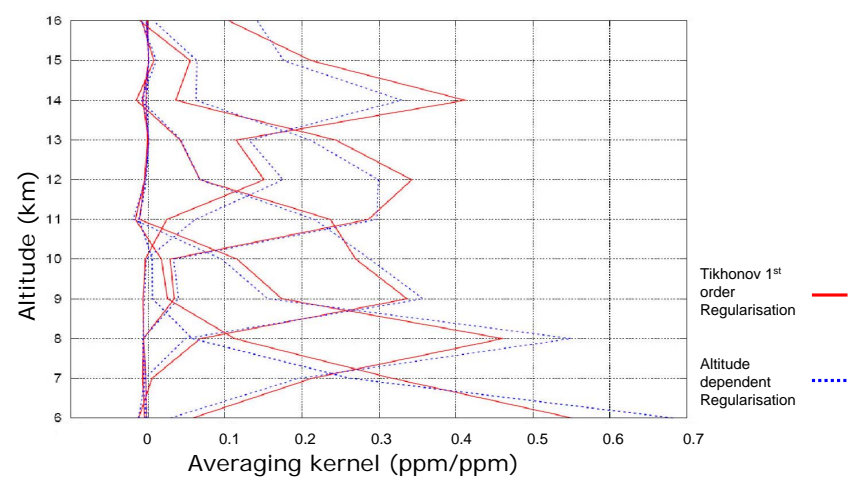

Fig. 4b. Averaging kernels for levels at 6, 8, 10, 12, and $14 \mathrm{~km}$ for one occultation. The red curve corresponds to a first order Tikhonov regularisation and the blue curve to an altitude dependent regularisation based on a Tikhonov first order operator.

$14 \mathrm{~km}$ for one occultation. Each averaging kernel represents the sensitivity of the $\mathrm{CO}_{2}$ value retrieved at this level with respect to a change in the true profile, its full width at half maximum corresponds to the vertical resolution. The blue curves correspond to the altitude dependent regularisation used here. In this case, we can estimate that the vertical resolution is around $2 \mathrm{~km}$ for the lowest altitudes and about $2.5 \mathrm{~km}$ at $15 \mathrm{~km}$. The estimated $\mathrm{CO}_{2}$ total error is characterized by a bias of about $\pm 1 \mathrm{ppm}$ and a standard deviation of about 2 ppm after averaging over 20 spatially and temporally consistent profiles (Fal2009). Averaging over fewer occultations may increase the total error, and is the reason why the minimum number of occultations has been set to 5 , corresponding to a mean standard deviation of about $5 \mathrm{ppm}$.

Five years (2004-2008) of ACE-FTS observations have been processed using the method briefly described above. Thoroughly validated, they will provide $\mathrm{CO}_{2}$ vertical profiles on a near global scale. Here, we focus on the time period 2004-2008 and the latitude bands $40^{\circ} \mathrm{N}-60^{\circ} \mathrm{N}$ and $50^{\circ} \mathrm{N}-$ $60^{\circ} \mathrm{N}$ that are well covered by ACE and for which in situ aircraft measurements of $\mathrm{CO}_{2}$ are available. For each month we obtain a mean profile covering the $10-25 \mathrm{~km}$ range using lines from the main $\mathrm{CO}_{2}$ isotopologue, as well as a mean profile covering the $5-15 \mathrm{~km}$ range using lines from the ${ }^{18} \mathrm{OC}^{16} \mathrm{O}$ isotopologue: the ${ }^{18} \mathrm{OC}^{16} \mathrm{O}$ isotopologue lines are employed because the main isotopologue lines become saturated at low altitude. As shown by Boone et al. (2005), we can expect an overestimation of $3.5 \%$ of the $\mathrm{CO}_{2}$ concentration retrieved from the ${ }^{18} \mathrm{OC}^{16} \mathrm{O}$ isotopologue due to either errors in the strengths of the ${ }^{18} \mathrm{OC}^{16} \mathrm{O}$ lines in the line list (here "GEISA", Jacquinet-Husson et al. (2008)) and/or to a difference in the mixing ratios from the expected ${ }^{18} \mathrm{OC}^{16} \mathrm{O} /{ }^{12} \mathrm{C}^{16} \mathrm{O}_{2}$ isotopic ratio. For each occultation, we estimate the ratio between $\mathrm{CO}_{2}$ concentrations retrieved from the ${ }^{18} \mathrm{OC}^{16} \mathrm{O}$ isotopologue lines and ${ }^{12} \mathrm{C}^{16} \mathrm{O}_{2}$ main isotopologue lines in the overlap region, between 10 and $15 \mathrm{~km}$. This ratio is then applied to the entire ${ }^{18} \mathrm{OC}^{16} \mathrm{O}$ isotopologue profile to build a unique profile from 5 to $25 \mathrm{~km}$. The mean ratio measured is about $2.5 \%$ in the $40-60^{\circ} \mathrm{N}$ latitude band, a value close to the $3.5 \%$ global mean value estimated by Boone et al. (2005). Finally, we apply a linear filter (Eq. 1) where $x$ is the $\mathrm{CO}_{2}$ concentration value and $z$ is the $1 \mathrm{~km}$ grid level, to smooth the final retrieved profile on the $1 \mathrm{~km}$ grid with a minor impact on the $2.5 \mathrm{~km}$ mean vertical resolution.

$x_{f}(z)=0.25 x(z+1)+0.5 x(z)+0.25 x(z-1)$

Averaged over the 2004-2006 time period, separately for each isotopologue, the $\mathrm{CO}_{2}$ profile monthly mean standard deviations (std), which result from both errors in the method and variability of the $\mathrm{CO}_{2}$ concentrations over one month in the latitude band considered (here $50^{\circ} \mathrm{N}-60^{\circ} \mathrm{N}$ ), vary with altitude and month. Smallest values, of the order of $2 \mathrm{ppm}$ or less, are observed between $12-13 \mathrm{~km}$ and $24 \mathrm{~km}$ in MayJuly and, to a lesser extent, September. Above $22 \mathrm{~km}$, std values may reach $4 \mathrm{ppm}$ in December-February, with a peak at $5 \mathrm{ppm}$ at $24 \mathrm{~km}$ in February. Below $12-13 \mathrm{~km}$, std values, as expected from the greater natural variability of the $\mathrm{CO}_{2}$ seasonal cycle at lower altitudes, are more variable. For most of the months, the std fluctuates around $3 \mathrm{ppm}( \pm 1 \mathrm{ppm})$ with larger values for ${ }^{18} \mathrm{OC}^{16} \mathrm{O}$ in particular at 10 and/or $11 \mathrm{~km}$. At these altitudes, the main isotopologue generally shows lower std values. Below $10 \mathrm{~km}$, where results come exclusively from the ${ }^{18} \mathrm{OC}^{16} \mathrm{O}$ isotopologue and fewer occultations contribute to the average, std values are below $4 \mathrm{ppm}$ except for a peak of almost 6 ppm in March. 


\section{Comparisons with aircraft in-situ measurements time-series}

Commercial aircraft-based observations using in situ measurement systems have made significant contributions to our present knowledge of the distribution of $\mathrm{CO}_{2}$ in the atmosphere. Major contributions include measurements of $\mathrm{CO}_{2}$ over Japan and the western Pacific (Nakazawa et al., 1991; Matsueda et al., 2002; Machida et al., 2008; Matsueda et al., 2008; Sawa et al., 2008), in particular with the ongoing CONTRAIL program. From Europe to the tropics measurements have been made available from the Civil Aircraft for the Regular Investigation of the Atmosphere Based on an Instrument Container (CARIBIC; Brenninkmeijer et al. $(1999,2007))$ program and from the SPURT (Spurenstofftransport in der Tropopausenregion/ trace gas transport in the tropopause region) campaigns in Europe (Hoor et al., 2004; Engel et al., 2006; Bönisch et al., 2008; Gurk et al., 2008). This section presents comparisons between ACE-FTS $\mathrm{CO}_{2}$ profiles and these in situ observations. These comparisons are not direct because they do not exactly match, in particular spatially. However, they provide important conclusions on the accuracy with which ACE/FTS may retrieve the $\mathrm{CO}_{2}$ trend and seasonal variations with altitude.

\section{1 $\mathrm{CO}_{2}$ in the upper troposphere $(9-10 \mathrm{~km})$}

ACE-retrieved upper tropospheric $\mathrm{CO}_{2}$ concentrations are first compared to results from the CARIBIC experiment as given in Schuck et al. (2009). These upper troposphere $\mathrm{CO}_{2}$ monthly mean concentration time series correspond to flights to Asia covering the latitudes from about $20^{\circ} \mathrm{N}$ to about $55^{\circ} \mathrm{N}$ and are compared in Fig. 5 to ACE monthly mean retrieved concentrations for the $40^{\circ} \mathrm{N}-60^{\circ} \mathrm{N}$ latitude band. A relatively good agreement is seen between the two sets of $\mathrm{CO}_{2}$ concentrations: the mean difference between the two polynomial fits (each fit uses a linear trend and two harmonics and a non linear iterative LevenbergMarquardt algorithm) to either the measurements or to the retrievals (Schuck et al., 2009) is less than 2 ppm. However, a temporal shift is observed between the two curves, with the ACE-FTS peaking about one month earlier than CARIBIC. We see two possible reasons for this difference: (i) the fact that CARIBIC covers latitudes that are on average smaller than ACE (the $40^{\circ} \mathrm{N}-60^{\circ} \mathrm{N}$ latitude band has been chosen to obtain as many non-polar occultations as possible) for which the peak is expected earlier, and, (ii) the difficulty in correctly positioning the minimum month because of the absence of ACE data for the months of August and October. The retrieved annual growth rate is about $1.9 \mathrm{ppm} . \mathrm{yr}^{-1}$ (+/-0.2 ppm) from 2005 to 2008 , (slope of the fit lines) in agreement with the mean annual growth rate observed at the surface for this time period (see, for example, http://www.esrl.noaa.gov/gmd/ccgg/trends/).
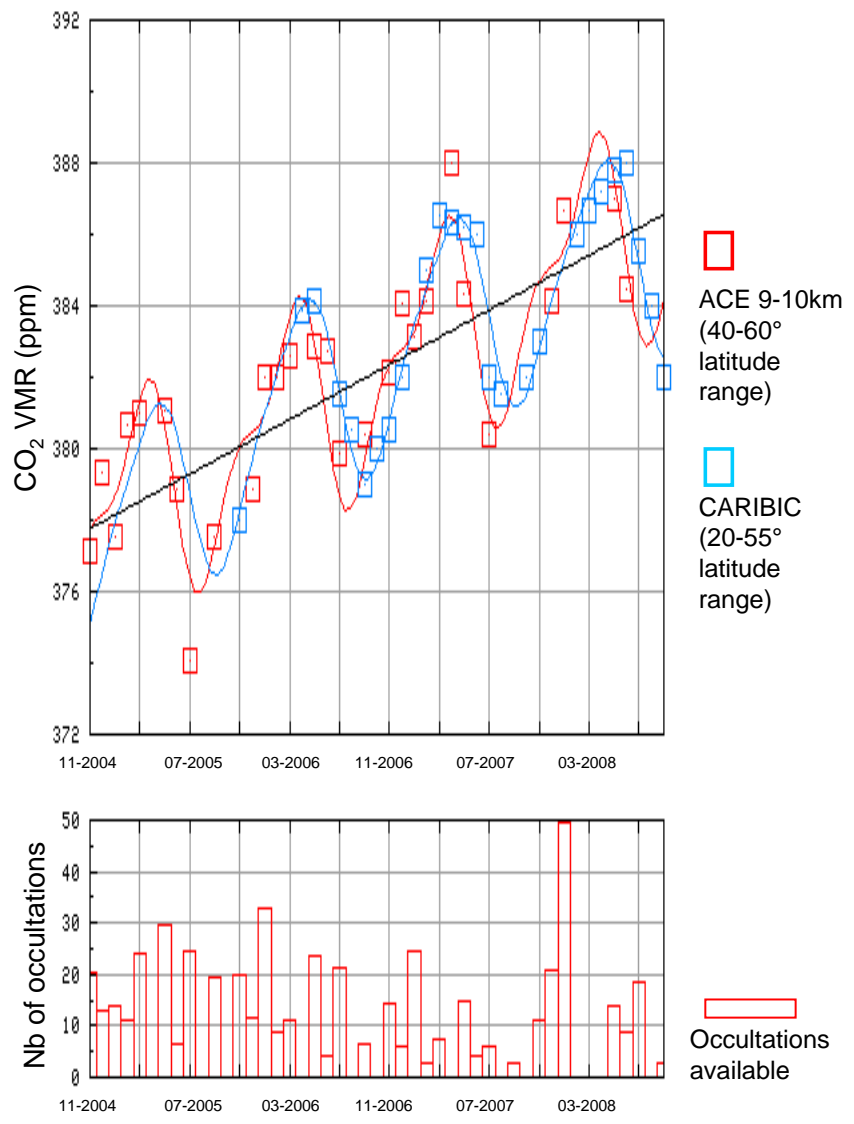

Fig. 5. Top: temporal evolution of $\mathrm{CO}_{2}$ concentration (y-axis in $\mathrm{ppm})$ in the upper troposphere $(9-10 \mathrm{~km})$. Blue boxes: ACE-FTS results for the $40^{\circ} \mathrm{N}-60^{\circ} \mathrm{N}$ latitude band; red boxes: CARIBIC measurements for the $20-55^{\circ} \mathrm{N}$ latitude band. The blue and red lines result from a curve fit using a harmonic polynomial (two harmonics). The slope of the best fit line corresponds to the mean growth rate during this time period: $1.9 \mathrm{ppm} . \mathrm{yr}^{-1}$. Bottom: number of ACE-FTS occultations used in the $9-10 \mathrm{~km}$ altitude range.

\section{2 $\mathrm{CO}_{2}$ below, around, and above the tropopause: from $8-9 \mathrm{~km}$ to $16-18 \mathrm{~km}$}

Figure 6 (top), which is similar to Fig. 5 but for the $50^{\circ} \mathrm{N}-$ $60^{\circ} \mathrm{N}$ latitude band and the 2004-2008 time period, displays time series of ACE-retrieved monthly mean $\mathrm{CO}_{2}$ concentrations for six atmospheric layers: 8-9 km, 9-10 km, 10$12 \mathrm{~km}, 11-13 \mathrm{~km}, 12-14 \mathrm{~km}$, and $16-18 \mathrm{~km}$, spanning the upper troposphere to the lower stratosphere. Monthly mean retrieved concentrations are represented by crosses and the curves result from the harmonic polynomial fit (two harmonics for the first two layers, one harmonic for the remaining four) to the retrievals at different altitudes. Figure 6 (bottom), from Sawa et al. (2008), also displays CONTRAIL $\mathrm{CO}_{2}$ time series measurements above Eurasia in a similar altitude range from November 2005 to September 2007. Figure 6 (top) can also be compared to results from SPURT (see Fig. 9 of Hoor et al. (2004) and Fig. 5 of Gurk et al. (2008)) 




Fig. 6. Top: Temporal evolution of $\mathrm{CO}_{2}$ concentration retrieved from ACE-FTS measurements for six atmospheric layers from 8 to $18 \mathrm{~km}$ (see color legend). Crosses show the retrievals (monthly mean) and the curves result from the harmonic polynomial fit (two harmonics for the first two layers, one for the remaining four) to the retrievals at different altitudes. Bottom: Temporal evolution of $\mathrm{CO}_{2}$ concentration from CONTRAIL measurements (Sawa et al., 2008) above Eurasia from November 2005 to September 2007. Each curve represents $\mathrm{CO}_{2}$ time series observed at $10 \mathrm{~K}$ potential temperature bins from the local tropopause. An approximate relationship between $\theta$ (potential temperature) and altitude is given at the bottom left of the figure. Blue curves correspond to the lower stratosphere and orange curves to the higher troposphere.

particulary in term of seasonal variations. ACE-retrieved $\mathrm{CO}_{2}$ vertical profiles, SPURT and CONTRAIL in situ measurements show key features of the $\mathrm{CO}_{2}$ distribution with altitude. First, the amplitude of the $\mathrm{CO}_{2}$ tropospheric seasonal cycle (detrended) decreases from 7-8 ppm below the tropopause at $9-10 \mathrm{~km}$ to $1-2 \mathrm{ppm}$ at $10-12 \mathrm{~km}$ and the amplitude increases again in the stratosphere at $16-18 \mathrm{~km}$, in agreement with the observations but with an amplitude (2-3 ppm) somewhat too large for the highest layer. As pointed out by Hoor et al. (2004), the phase of the cycle remains tropospheric with a minimum in summer up to the lowermost stratosphere at $10-12 \mathrm{~km}$, reflecting the strong coupling between the lowermost stratosphere and the extra-tropical troposphere through troposphere to stratosphere transport of air that entered the stratosphere at the tropical tropopause. The dampening of the amplitude of the seasonal cycle reflects the role of the extratropical tropopause as a barrier to transport (Hoor et al., 2004). Above, the phase maximum is shifted by up to three months towards summer as observed in-situ. Second, a negative vertical gradient is clearly seen in Fig. 6 in August which accurately reproduces the negative gradient seen by SPURT and by CONTRAIL. This leads to a significant vertical gradient during winter and spring, and to a very weak gradient (sometimes positive) from 9 to $18 \mathrm{~km}$ in summer and fall. Third, at all altitudes the $\mathrm{CO}_{2}$ concentration exhibits a mean temporal trend of about $1.9 \mathrm{ppm} . \mathrm{yr}^{-1}$, again in good agreement with the mean annual growth rate observed at the surface for this time period.

These comparisons show that the $\mathrm{CO}_{2}$ concentrations retrieved from ACE-FTS are consistent with aircraft in situ measurements in the northern hemisphere mid-latitudes. In particular, the mean growth rate, the seasonal vertical gradient change and phase shift from the mid-troposphere to the lower stratosphere are well represented by ACE-retrieved $\mathrm{CO}_{2}$ values. However the stratosphere seasonal cycle amplitude seems to be over-estimated. A possible explanation could come from the difference in the spatial coverage of the different data sets. Indeed, ACE-FTS results sum all latitudes and longitudes in the $50^{\circ} \mathrm{N}-60^{\circ} \mathrm{N}$ band, whereas SPURT, CARIBIC, and CONTRAIL data correspond to observations above Europe, Eurasia, and Asia, respectively. 


\section{Comparisons with air-transport model $\mathrm{CO}_{2}$ profiles}

Another way of assessing the quality of the ACE-retrieved $\mathrm{CO}_{2}$ vertical profiles is to compare them with air transport model simulations. For that purpose, two well known models have been used. First, we consider the Flexpart Lagrangian particulate dispersion model (Stohl et al., 2005) driven with meteorological input data (wind, temperature and humidity fields) from the European Centre for Medium Range Weather Forecasts (ECMWF). $\mathrm{CO}_{2}$ surface data from the World Data Centre for Greenhouse Gases (WDCGG, http://gaw.kishou.go.jp/wdcgg) have been used to create a source function for the lower most troposphere. $\mathrm{CO}_{2}$ fields from a six-year analysis have been monthly averaged for $10^{\circ}$ latitude bands to make comparisons with profiles retrieved from ACE-FTS for the year 2006. The second model considered generates $\mathrm{CO}_{2}$ model simulations from the CarbonTracker (2009, http://carbontracker.noaa.gov) system (Peters et al., 2007). Carbon Tracker (CT) is based on the TM5 model, which is a global atmospheric chemistry-transport zoom model (Krol et al., 2005) optimized with highly accurate $\mathrm{CO}_{2}$ measurements at the Earth's surface from the NOAA/ESRL network. Results have been averaged monthly for the $50^{\circ} \mathrm{N}-60^{\circ} \mathrm{N}$ latitude band to make comparisons with retrieved profiles from ACE-FTS for the years 2005 to 2008.

\subsection{Monthly averaged $\mathrm{CO}_{2}$ profiles}

Figures 7 to 10 show model simulations (either CT alone or both CT and Flexpart) and ACE- retrieved profiles from 2005 to 2008, respectively, for the two months of May and July for the $50^{\circ} \mathrm{N}-60^{\circ} \mathrm{N}$ latitude band. These two months are well represented with respect to the number of occultations available and show contrasting properties in terms of atmospheric transport. Both CT and Flexpart model standard deviations are around $1 \mathrm{ppm}$ and ACE-retrieved profile standard deviation is about $4 \mathrm{ppm}$ for the lowest altitude and about 2-3 ppm above. Figure 7 corresponds to 2005; ACE-retrieved profiles start around 400-500 $\mathrm{hPa}$ in the troposphere. Comparisons with CT profiles show a good overall agreement from 400 $\mathrm{hPa}$ to $70 \mathrm{hPa}$ with a mean difference of less than $2 \mathrm{ppm}$. ACE values in May from $180 \mathrm{hPa}$ to $70 \mathrm{hPa}$ are smaller than the model values by about $2 \mathrm{ppm}$ (however, less than $10 \mathrm{oc}-$ cultations on average, are available). The large vertical gradient is seen by both products. In July, the ACE retrieved profile shows no vertical gradient contrary to CT that shows a "peak" of about $+3 \mathrm{ppm}$ at about $180 \mathrm{hPa}$ with respect to the $500 \mathrm{hPa}$ value. Observations from SPURT show almost no gradient in July 2002 (Hoor et al., 2004) and observations from CONTRAIL show a gradient of about $4 \mathrm{ppm}$ in July and of about 3 ppm in July 2007. Both ACE and CT however agree on a gradient that is much smaller in July than in May.

Figure 8 shows Flexpart, $\mathrm{CT}$ and ACE-retrieved $\mathrm{CO}_{2}$ profiles in the $50^{\circ} \mathrm{N}-60^{\circ} \mathrm{N}$ latitude band for the months of May and July 2006. A rather good agreement is found between
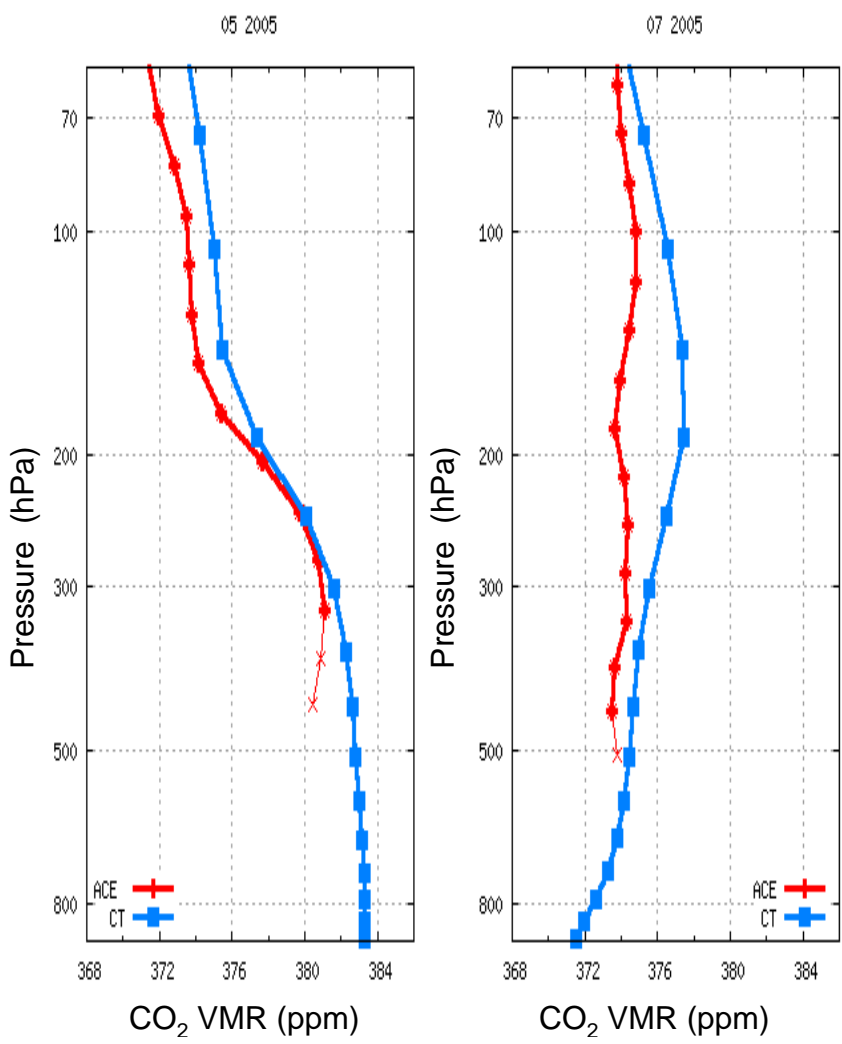

Fig. 7. $\mathrm{CO}_{2}$ concentration (x-axis in $\mathrm{ppm}$ ) evolution with pressure (y-axis in $\mathrm{hPa}$ ) for May (left) and July (right) for 2005 for the $50^{\circ} \mathrm{N}-60^{\circ} \mathrm{N}$ latitude band. ACE-retrieved profile is in red and CT profile is in blue. The thin red line indicates that less than 10 occultations were available. ACE $\mathrm{CO}_{2}$ standard deviation at each altitude (not shown in the picture) fluctuates around $3 \mathrm{ppm}( \pm 1 \mathrm{ppm})$.

these three sets of profiles. The difference is less than $2 \mathrm{ppm}$ for most of the altitudes. In May, the Flexpart and CT profiles are very consistent in the troposphere whereas the difference reaches $2 \mathrm{ppm}$ above the tropopause. The ACE-retrieved profile shows lower values (1.5 ppm) below $300 \mathrm{hPa}$ and is closer to the Flexpart profile up to $100 \mathrm{hPa}$. At higher altitudes, a significant decrease in the ACE retrieved-profile is observed, not seen by the models. Between 100 and $200 \mathrm{hPa}$, ACE is between the two models. In July, the Flexpart profile is about $1 \mathrm{ppm}$ higher than the CT profile at all the altitudes. ACE is closer to $\mathrm{CT}$ at lower altitudes and closer to Flexpart at higher altitudes. The vertical gradient is somewhat smaller for ACE than for the models.

Figure 9 shows results similar to Fig. 7 for the year 2007. The agreement between ACE-retrieved and CT simulated profiles is again good with a mean difference less than $1 \mathrm{ppm}$ and gradients similar in May and slightly smaller for ACE in July. ACE-retrieved concentrations in the troposphere and higher in the stratosphere compare well with the model.

Figure 10 shows results similar to Fig. 7 for the year 2008. Here, the agreement is significantly worse with a mean 

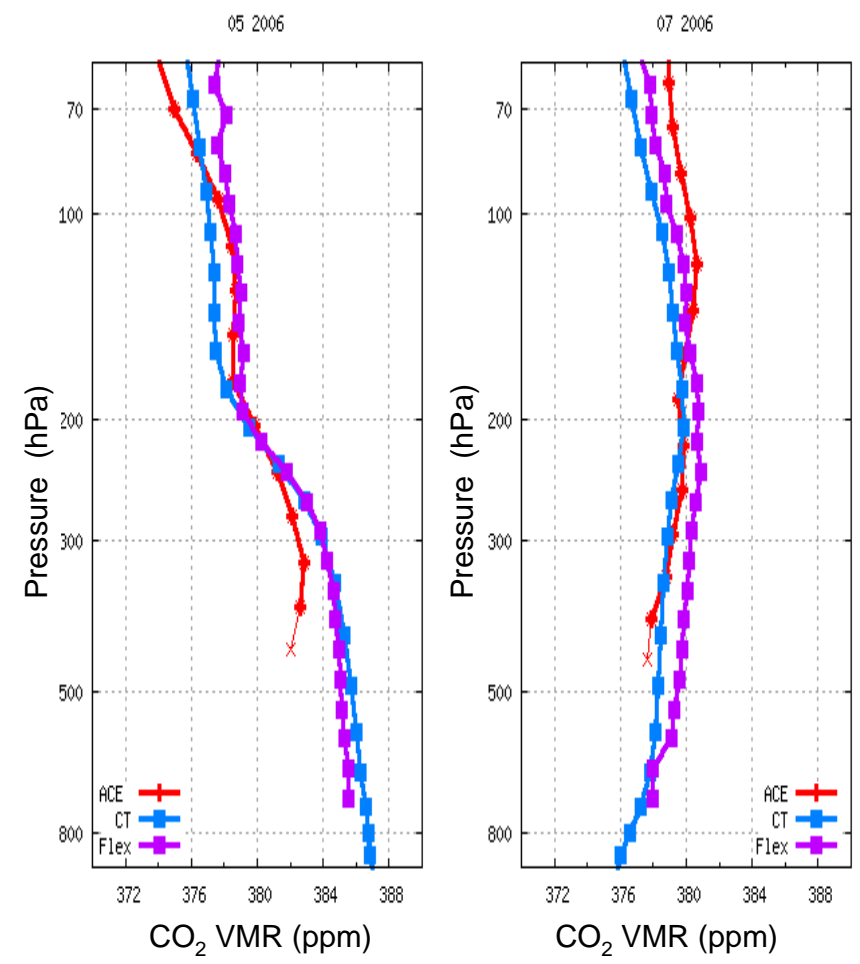

Fig. 8. $\mathrm{CO}_{2}$ concentration (x-axis in ppm) evolution with pressure (y-axis in hPa) for May (left) and July (right) of 2006 for the $50^{\circ} \mathrm{N}-$ $60^{\circ} \mathrm{N}$ latitude band. ACE-retrieved profile is in red, CT profile is in blue and Flexpart profile is in purple. ACE thin red line indicates that less than 10 occultations were available. $\mathrm{ACE} \mathrm{CO}_{2}$ standard deviation at each altitude (not shown in the picture) fluctuates around 3 ppm $( \pm 1 \mathrm{ppm})$.

difference of about $2 \mathrm{ppm}$ especially above $250 \mathrm{hPa}$ in May and $200 \mathrm{hPa}$ in July. The difference is smaller in the troposphere. The tropopause transition is smoother for ACE in May and steeper in July where a larger ACE gradient is seen.

It must be pointed out that, for all years, the July peak value seen at about $200 \mathrm{hPa}$ in CT profiles is also seen in ACE profiles but at significantly higher altitudes (except in 2006, where no peak value is seen in ACE profile).

These comparisons show that the $\mathrm{CO}_{2}$ concentration profiles retrieved from ACE-FTS observations are quite consistent with model simulations in the northern hemisphere midlatitudes for two particular months characterized by either a strong vertical gradient (May) or a weak (or no) gradient (July). The largest differences ( $3 \mathrm{ppm}$ ) are observed for the latter month.

\subsection{Can a temporal shift of the model profiles improve the agreement with ACE-retrieved profiles?}

Current problems with air-transport models have been briefly summarized in the Introduction. These model deficiencies can cause over or under estimation of tracer profiles, with the
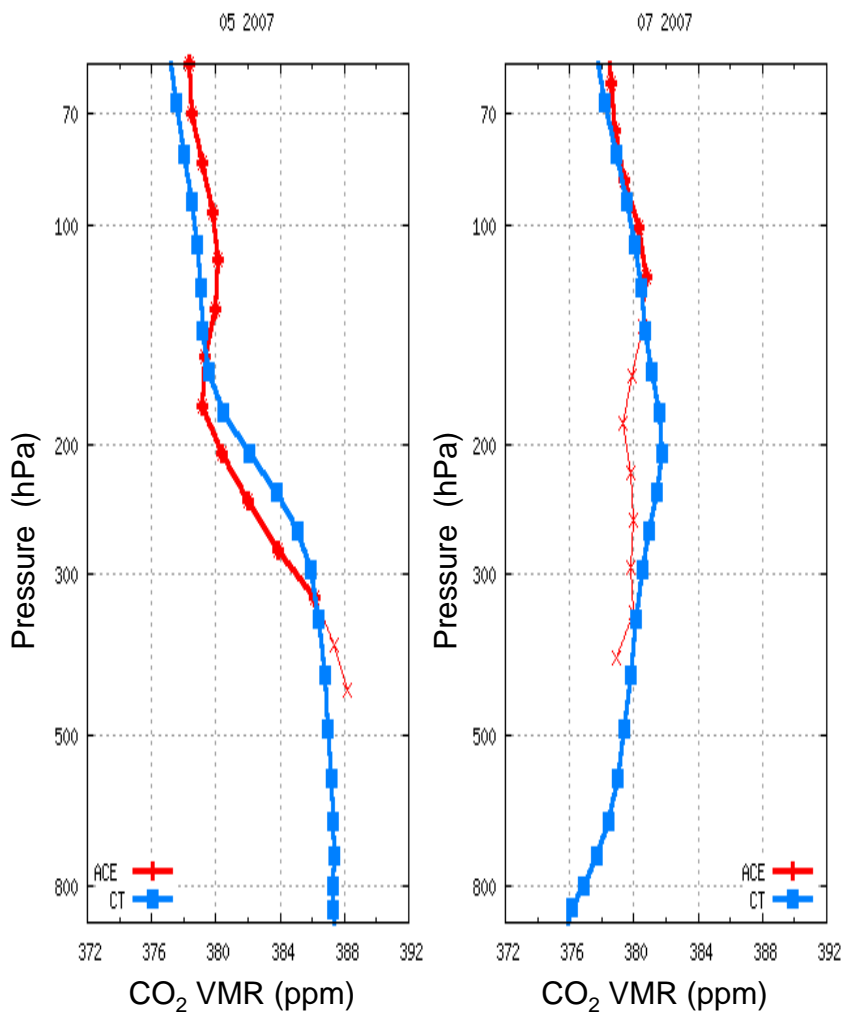

Fig. 9. Same as Fig. 7 for 2007.

anomalies depending on the time of year and on the altitude (troposphere or stratosphere). As a consequence, a profile retrieved at a given month might more favourably be compared with a profile simulated by the model for the month just before or just after the month considered.

In this section we look for such temporal shifts between model profile simulations and ACE-retrieved profiles. We examine two years: 2006 which presents the best general agreement between ACE and CT, and 2008 which corresponds to the poorest agreement.

Figure 11 shows, for the $50^{\circ} \mathrm{N}-60^{\circ} \mathrm{N}$ latitude band, ACEretrieved profiles for May and July 2006 together with Flexpart and CT profiles for the months just after (June and August; top row) and for the months just before (April and June; bottom row). Although the original comparison showed generally good agreement (see Fig. 8), a slight improvement is seen when comparing ACE in May to CT in June above $200 \mathrm{hPa}$ and a more significant improvement in the agreement is seen when comparing ACE to both CT and Flexpart below $200 \mathrm{hPa}$ (top-left). A slight degradation is observed when comparing ACE in May to both Flexpart and CT in April (bottom-left). A similar agreement is found when comparing ACE in July to both models in August, except that ACE agrees better with Flexpart below $200 \mathrm{hPa}$ than with CT (top-right); a strong degradation is observed when comparing ACE in July to both Flexpart and CT in June (bottom-right). 

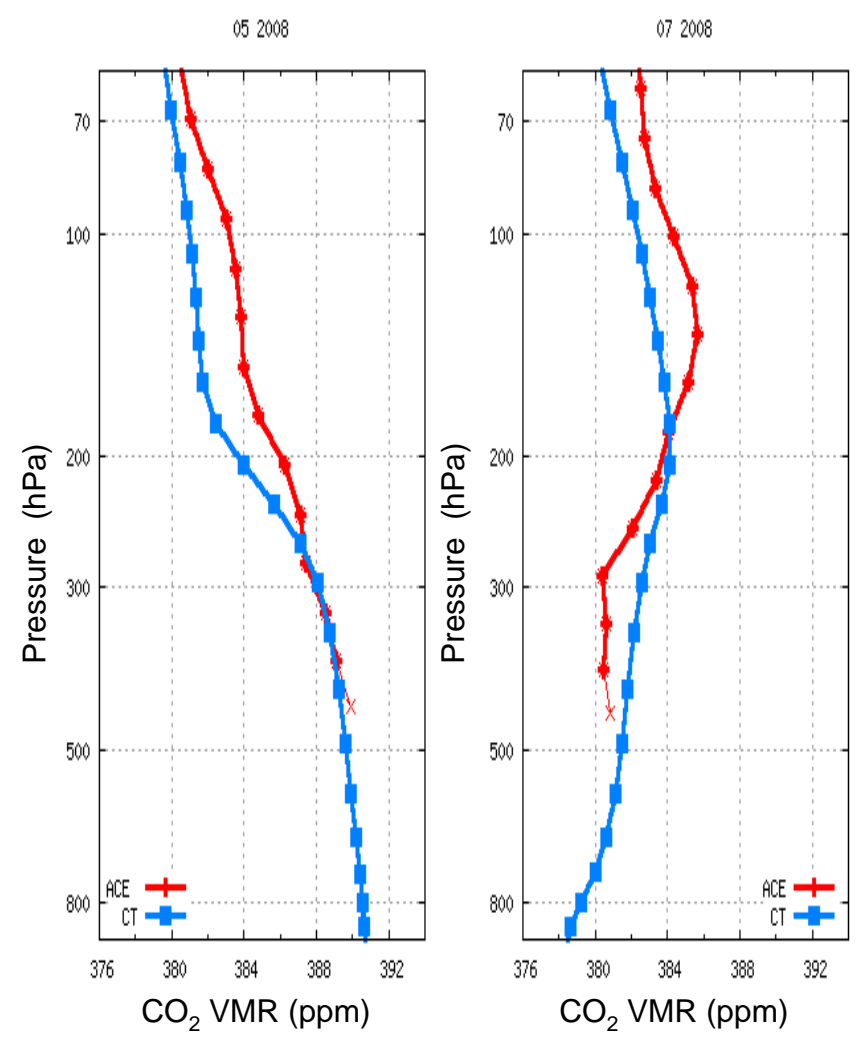

Fig. 10. Same as Fig. 7 for the year 2008.
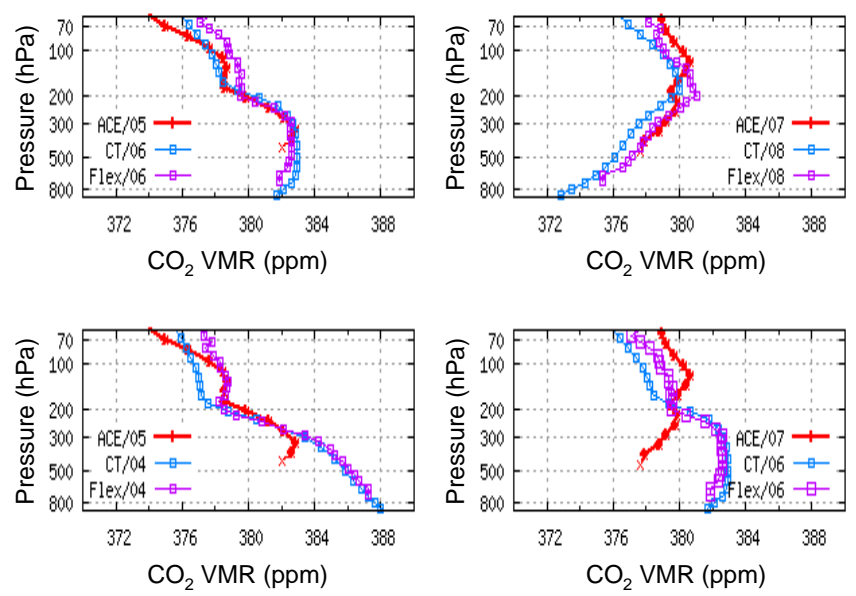

Fig. 11. Flexpart (purple), $\mathrm{CT}$ (blue), and $\mathrm{ACE}$ (red) $\mathrm{CO}_{2}$ profiles for the $50^{\circ} \mathrm{N}-60^{\circ} \mathrm{N}$ latitude band in 2006. ACE profiles in May (left) and July (right) are compared to Flexpart and CT profiles of one month before (top), and of one month after (bottom). ACE thin red line indicates that less than 10 occultations were available.

Figure 12 shows, for the $50^{\circ} \mathrm{N}-60^{\circ} \mathrm{N}$ latitude band, ACEretrieved profiles for May and July 2008 together with Flexpart profiles for the months just after (June and August; top row) and for the months just before (April and June; bottom row). Compared to Fig. 10, the ACE profile in May agrees
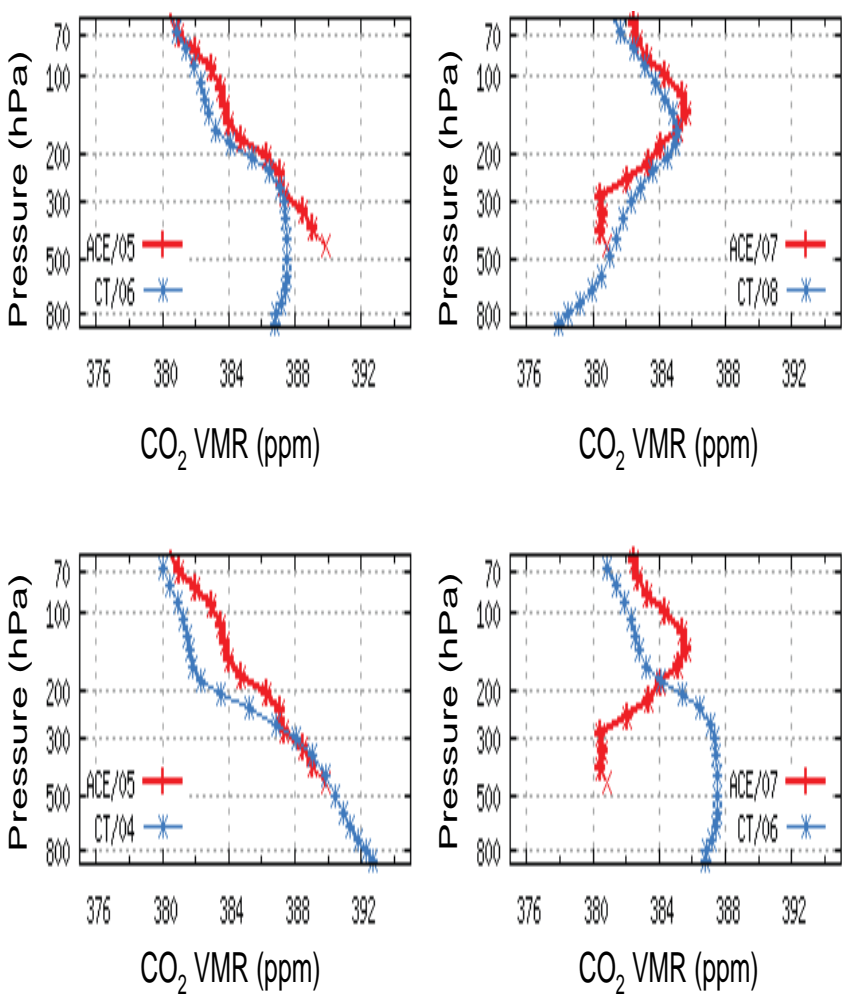

Fig. 12. $\mathrm{CT}$ (blue) and $\mathrm{ACE}$ (red) $\mathrm{CO}_{2}$ profiles for the $50^{\circ} \mathrm{N}-60^{\circ} \mathrm{N}$ latitude band in 2008. ACE profiles in May (left) and July (right) are compared to CT profiles of one month before (top), and of one month after (bottom). ACE thin red line indicates that less than 10 occultations were available.

better with the CT profile in June above $300 \mathrm{hPa}$ but the fit is poorer below (top-left); the agreement is similar when comparing ACE in May to CT in April (bottom-left). Compared to Fig. 10, the ACE profile in July agrees slightly better with the CT profile in August (top-right); the agreement is much poorer when comparing ACE in May to CT in June (bottomright).

A provisional conclusion from this very limited exercise is that ACE-retrieved profiles agree better with model profiles for the month just after the ACE month considered. More comparisons are obviously required before concluding there is deficiency in the models or possible problems with the retrievals.

A general agreement between model-simulated and ACEretrieved profiles for the $50^{\circ} \mathrm{N}-60^{\circ} \mathrm{N}$ latitude band in May and July is evident from this comparison. However, differences are observed notably above and around the tropopause region. We also observe that comparing the ACE profile in May to model profiles in April improves the fit (mean and standard deviation) for all years considered here. The improvement is less significant in July. A strong degradation generally occurs when comparing ACE profiles in July to model profiles in June. This suggests that the model 
circulation strength might be over estimated during the northern hemisphere spring. Obviously, this does not exclude errors in the retrieval method and many more comparisons of retrievals vs. models are required before a convincing conclusion can be drawn.

\section{Conclusions}

In this paper we have presented, for the first time in the 5$25 \mathrm{~km}$ altitude range, five years of monthly mean $\mathrm{CO}_{2}$ vertical profiles from the ACE-FTS limb-viewing space-borne instrument (Bernath et al., 2005). After having briefly reviewed the inversion approach described in detail in Fal2009, results obtained for the 2004-2008 time period and for the $40^{\circ} \mathrm{N}-60^{\circ} \mathrm{N}$ and $50^{\circ} \mathrm{N}-60^{\circ} \mathrm{N}$ latitude bands have been compared with in situ aircraft measurements from the CONTRAIL (Sawa et al., 2008), CARIBIC (Schuck et al., 2009), and SPURT (Gurk et al., 2008) in situ aircraft measurements, as well as with two air transport model $\mathrm{CO}_{2}$ profile simulations: Flexpart (Stohl et al., 2005) and Carbon Tracker (Peters et al., 2007). These comparisons have shown that the $\mathrm{CO}_{2}$ concentrations retrieved from ACE-FTS are consistent with aircraft measurements in the northern hemisphere mid-latitudes. In particular, the mean growth rate, the seasonal vertical gradient change and phase shift from the midtroposphere to the lower stratosphere are well represented by ACE-retrieved $\mathrm{CO}_{2}$ values. However the stratosphere seasonal cycle amplitude $(16-18 \mathrm{~km})$ seems somewhat over estimated. A possible explanation could come from the difference in the spatial coverage of the different data sets. Indeed, ACE-FTS results cover all latitudes and longitudes of the $40^{\circ} \mathrm{N}-60^{\circ} \mathrm{N}$ and $50^{\circ} \mathrm{N}-60^{\circ} \mathrm{N}$ bands, whereas SPURT, CARIBIC, and CONTRAIL data correspond to observation above Europe, Eurasia, and Asia, respectively. Comparisons for two particular months, May (characterized by a strong vertical gradient) and July (characterized by a weak - or no gradient) have shown that the $\mathrm{CO}_{2}$ concentration profiles retrieved from ACE-FTS observations are quite consistent with model simulations in the northern hemisphere mid-latitudes. However, differences are observed notably above and around the tropopause region. Current deficiencies in air-transport models may cause over or under estimates of tracer profiles, and these anomalies depend on the time of the year and on the altitude (troposphere or stratosphere). For this reason, we looked for temporal shifts between model profile simulations and ACE-retrieved profiles and observed that comparing ACE profiles in May to model profiles in April improves the fit for all the years considered here. The improvement is less significant in July. A strong degradation generally occurs when comparing ACE profiles in July to model profiles in June. This suggests that the model circulation strength is over estimated during the northern hemisphere spring. Obviously, this does not exclude errors in the retrieval method and more comparisons are required before a firm conclusion can be drawn. Future developments include: (i) the improvement of the modelling of the $\mathrm{N}_{2}$ continuum absorption; (ii) the processing of the years 2009 and 2010; (iii) the analysis of other latitude bands and specific geographic regions with a better space-time resolution.

This new ACE-FTS $\mathrm{CO}_{2}$ profile database provides information on air transport and data for assimilation into models. Coupled with column measurements from a nadir viewing instrument, it may also be expected that occultation measurements will bring useful constraints to the surface carbon flux determination.

\section{Appendix A}

\section{ACE retrieved monthly mean profiles from 2004 to 2008}

We present in this appendix (Fig. A1 to A3) monthly averaged ACE-retrieved $\mathrm{CO}_{2}$ profiles for the nine months available in the $50^{\circ} \mathrm{N}-60^{\circ} \mathrm{N}$ latitude band.

Acknowledgements. The ACE mission is supported primarily by the Canadian Space Agency (CSA) and some support was provided by the Natural Environment Research Council (NERC) of the UK. We gratefully acknowledge J. M. Hartmann for providing us with the $\mathrm{N}_{2}$ continuum CIA laboratory measurements and for fruitful discussions which led to their integration in our RTM. CarbonTracker 2009 results were provided by NOAA ESRL, Boulder, Colorado, USA through the website at http://carbontracker.noaa.gov. We especially wish to thank A. Jacobson and W. Peters for their help. Warm thanks are also extended to N. A. Scott and to V. Capelle for their important contributions to the development of the Radiative Transfer Model used here and to B. Legras for his help in the handling of the Flexpart model. We are happy to thank the two anonymous reviewers for their constructive and helpful comments.

Edited by: P. O. Wennberg

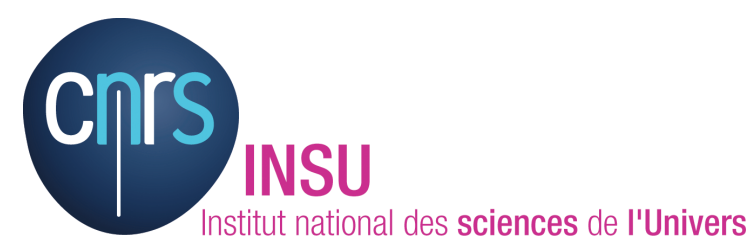

The publication of this article is financed by CNRS-INSU. 
01/2005

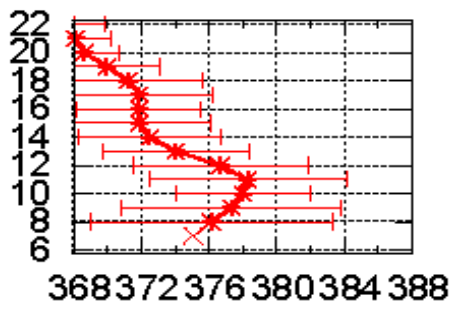

$05 / 2005$

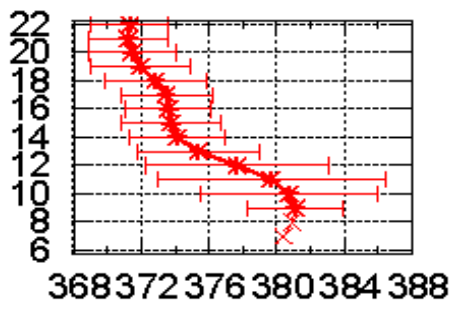

09/2005

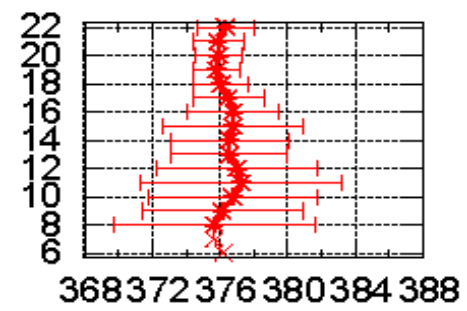

02/2005

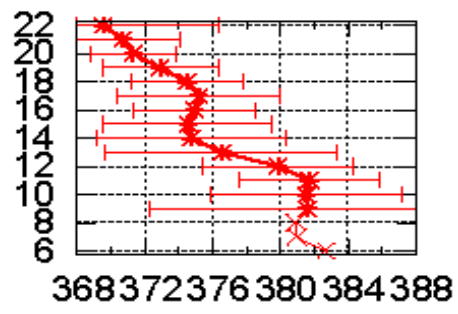

06/2005

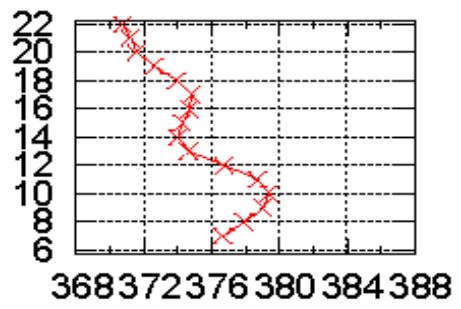

$11 / 2005$

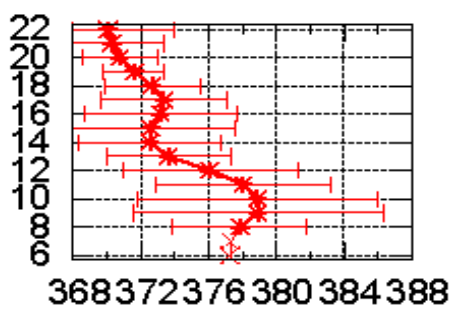

03/2005

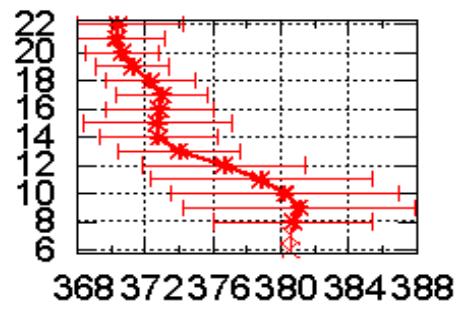

07/2005

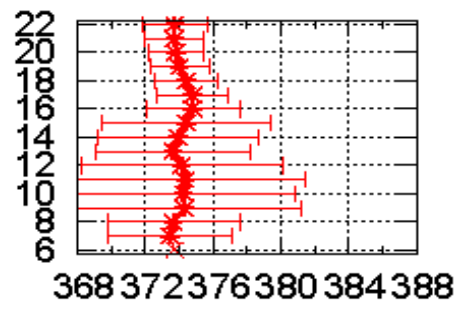

$12 / 2005$

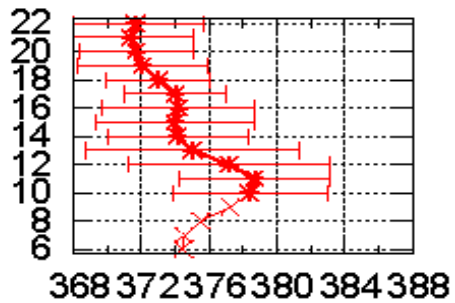

Fig. A1. Monthly mean $\mathrm{CO}_{2}$ concentration (x-axis in ppm) evolution with altitude (y-axis in $\mathrm{km}$ ) for nine months of 2005 for the $50^{\circ} \mathrm{N}-$ $60^{\circ} \mathrm{N}$ latitude band. Horizontal bars correspond to the standard deviation of retrieved $\mathrm{CO}_{2}$ profiles for each altitude. ACE thin red line indicates that less than 10 occultations were available; in that case, standard deviation is not estimated.

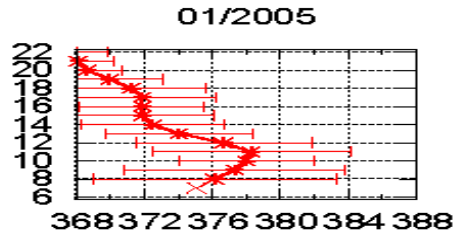

$05 / 2005$

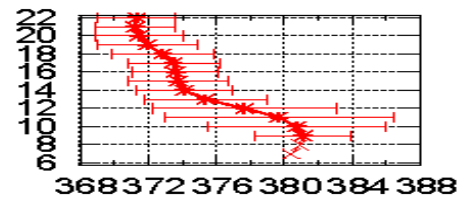

$09 / 2005$

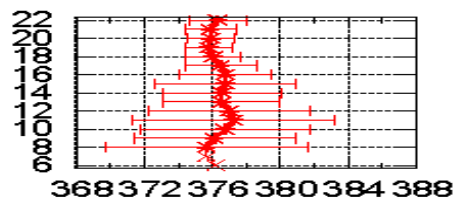

$02 / 2005$

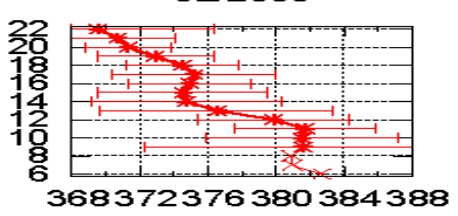

$06 / 2005$

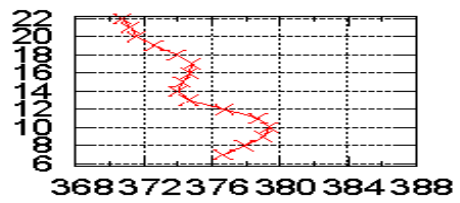

$11 / 2005$

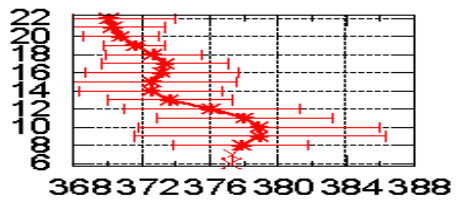

$03 / 2005$

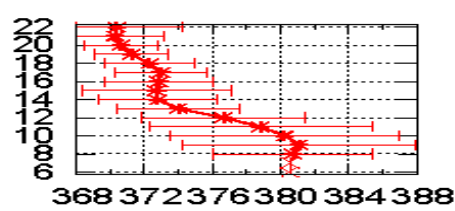

$07 / 2005$

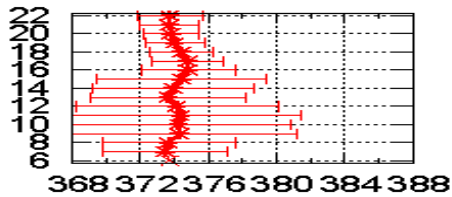

$12 / 2005$

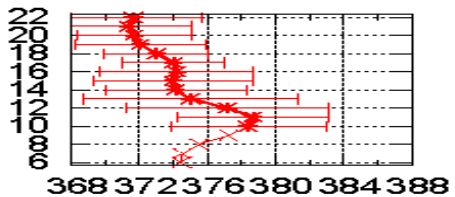

Fig. A2. Same as Fig. A1 for 2006. 
$01 / 2007$

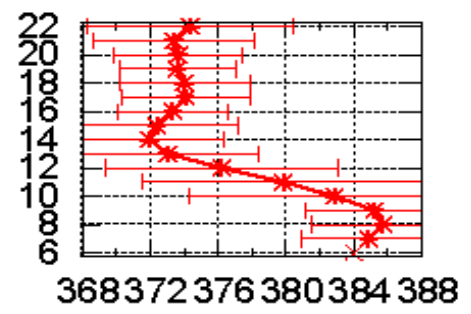

$05 / 2007$

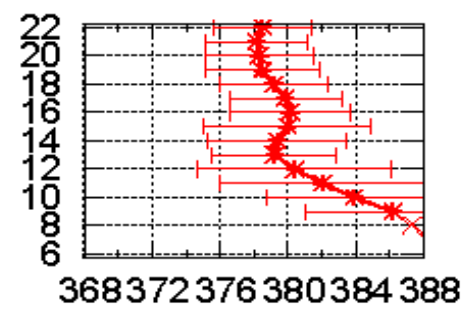

$09 / 2007$

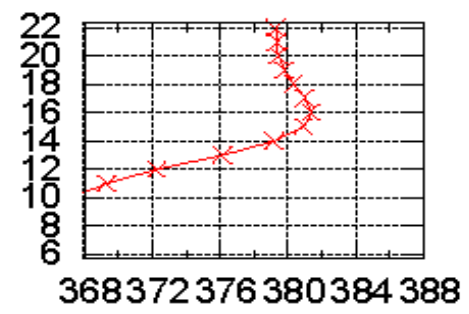

$02 / 2007$

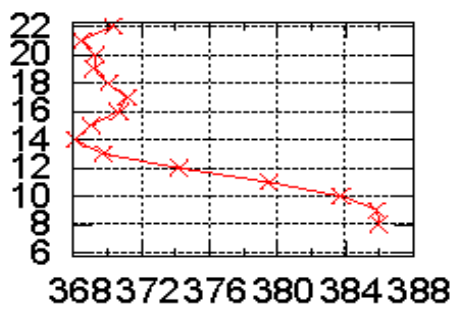

$06 / 2007$

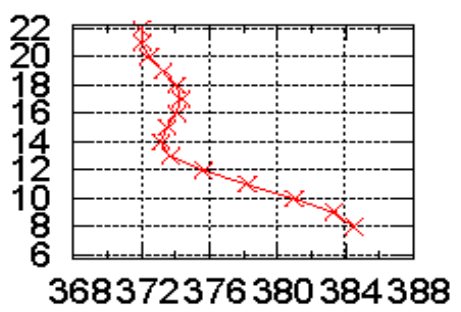

$11 / 2007$

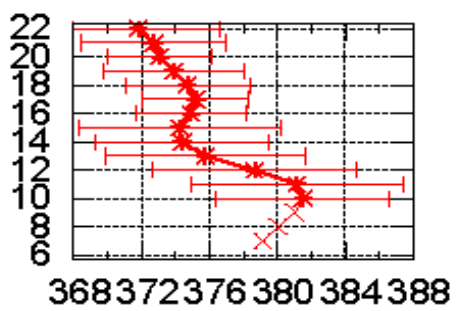

$03 / 2007$

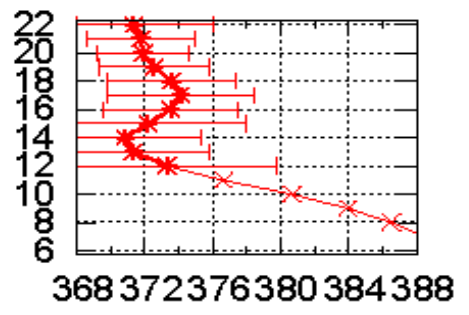

$07 / 2007$

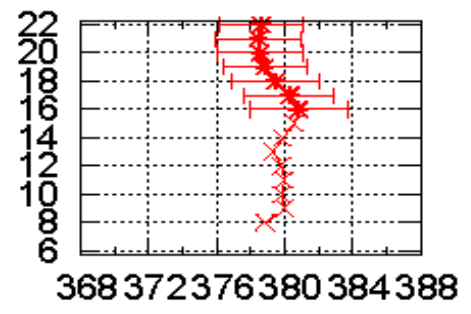

$12 / 2007$

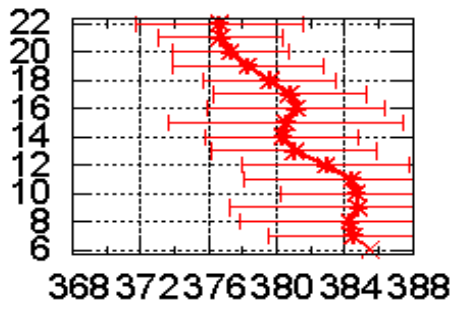

Fig. A3. Same as Fig. A1 for 2007.

\section{References}

Anderson, B., Gregory, G., Collins, J. J., Sachse, G., Conway, T., and Whiting, G.: Airborne observations of spatial and temporal variability of tropospheric carbon dioxide, J. Geophys. Res., 101, 1985-1997, 1996.

Andrew, A. E., Boering, K. A., Daube, B. C.,Wofsy, S. C., Loewenstein, M., Jost, H., Podolske, J. R.,Webster, C. R., Herman, R. L., Scott, D. C., Flesch, G. J., Moyer, E. J., Elkins, J. W., Dutton, G. S., Hurst, D. F., Moore, F. L., Ray, E. A., Romashkin, P. A., and Strahan, S. E.: Mean ages of stratospheric air derived from in situ observations of $\mathrm{CO}_{2}, \mathrm{CH}_{4}$, and $\mathrm{N}_{2} \mathrm{O}$, J. Geophys. Res., 106, 32295-32314, 2001.

Baker, D. F., Law, R. M., Gurney, K. R., Rayner, P., Peylin, P., Denning, A. S., Bousquet, P., Bruhwiler, L., Chen, Y. H., Ciais, P., Fung, I. Y., Heimann, M., John, J., Maki, T., Maksyutov, S., Masarie, K., Prather, M., Pak, B., Taguchi, S., and Zhu, Z.: TransCom3 inversion intercomparison: Interannual variability of regional $\mathrm{CO}_{2}$ fluxes, Global Biogeochem. Cy., 1988-2003, doi:10.1029/2004GB002439, 2006.

Beagley, S. R., Boone, C. D., Fomichev V. I., Jin, J. J., Semeniuk, K., McConnell, J. C., Bernath, P. F.: First multi-year occultation observations of $\mathrm{CO}_{2}$ in the MLT by ACE satellite: observations and analysis using the extended CMAM, Atmos. Chem. Phys.,
10, 1133-1153, 2010,

http://www.atmos-chem-phys.net/10/1133/2010/.

Bernath, P. F.: Atmospheric Chemistry Experiment (ACE): Analytical Chemistry from Orbit, Trends Anal. Chem., 25, 647-654, 2006.

Bernath, P. F., McElroy, C. T., Abrams, M. C., Boone, C. D., Butler, M., Camy-Peyret, C., Carleer, M., Clerbaux, C., Coheur, P.-F., Colin, R., DeCola, P., DeMaziere, M., Drummond, J. R., Dufour, D., Evans, W. F. J., Fast, H., Fussen, D., Gilbert, K., Jennings, D. E., Llewellyn, E. J., Lowe, R. P., Mahieu, E., Mc-Connel, J. C., McHugh, M., Mcleod, S. D., Michaud, R., Midwinter, C., Nassar, R., Nichitiu, F., Nowland, C., Rinsland, C. P., Rochon, Y. J., Rowlands, N., Semeniuxk, K., Simon, P., Skelton, R., Sloan, J. J., Soucy, M. A., Strong, K., Tremblay, P., Turnbull, D., Walker, K. A., Walkty, I., Wardle, D. A., Wehrle, V., Zander, R., and Zou, T.: Atmospheric Chemistry Experiment (ACE): Misson overview, Geophys. Res. Lett., 32, L15S01, doi:10.1029/2005GLO22386, 2005.

Bönisch, H., Hoor, P., Gurk, C., Feng, W., Chipperfield, M., Engel, A., and Bregman, B.: Model evaluation of $\mathrm{CO}_{2}$ and $\mathrm{SF}_{6}$ in the extratropical UT/LS region, J. Geophys. Res., 113, D06101, doi:10.1029/2007JD008829, 2008.

Boone, C. D., Nassar, R.,Walker, K. A., Rochon, Y., Mcleod, S. D., Rinsland, C. P., and Bernath, P. F.: Retrievals for the Atmo- 
spheric Chemistry Experiment Fourier-Transform Spectrometrer, App. Opt., 44, 7218-7231, 2005.

Brenninkmeijer, C. A. M., Crutzen, P. J., Fischer, H., Gsten, H., Hans, W., Heinrich, G., Heintzenberg, J., Hermann, M., Immelmann, T., Kersting, D., Maiss, M., Nolle, M., Pitscheider, A., Pohlkamp, H., Scharffe, D., Specht, K., and Wiedensohler, A.: CARIBIC: Civil Aircraft for Global Measurement of Trace Gases and Aerosols in the Tropopause Region, J. Atmos. Ocean. Tech., 16, 1373-1383, 1999.

Brenninkmeijer, C. A. M., Crutzen, P., Boumard, F., Dauer, T., Dix, B., Ebinghaus, R., Filippi, D., Fischer, H., Franke, H., Frie?, U., Heintzenberg, J., Helleis, F., Hermann, M., Kock, H. H., Koeppel, C., Lelieveld, J., Leuenberger, M., Martinsson, B. G., Miemczyk, S., Moret, H. P., Nguyen, H. N., Nyfeler, P., Oram, D., O'Sullivan, D., Penkett, S., Platt, U., Pupek, M., Ramonet, M., Randa, B., Reichelt, M., Rhee, T. S., Rohwer, J., Rosenfeld, K., Scharffe, D., Schlager, H., Schumann, U., Slemr, F., Sprung, D., Stock, P., Thaler, R., Valentino, F., van Velthoven, P., Waibel, A., Wandel, A., Waschitschek, K., Wiedensohler, A., Xueref-Remy, I., Zahn, A., Zech, U. and Ziereis, H.: Civil aircraft for the regular investigation of the atmosphere based on an instrumented container: The new CARIBIC system, Atmos. Chem. Phys., 7, 4943-4976, doi:10.5194/acp-7-4943-2007, 2007.

Buchwitz, M., de Beek, R., Noel, S., Burrowsandi, J. P., Bovensmann, H., Bremer, H., Bergamaschi, P., Krner, S., and Heimann, M.: Carbon monoxide, methane and carbon dioxide columns retrieved from SCIAMACHY by WFM-DOAS: year 2003 initial data set., Atmos. Chem. Phys., 5, 3313-3329, doi:10.5194/acp5-3313-2005, 2005.

Chédin, A., Serrar, S., Armante, R., Scott, N. A., and Hollingsworth, A.: Signatures of annual and seasonal variations of $\mathrm{CO}_{2}$ and other greenhouse gases from comparisons between NOAA/TOVS observations and model simulations, J. Climate, 15, 95-116, 2002.

Chédin, A., Scott, N. A., Crevoisier, C., and Armante, R.: First global measurement of mid-tropospheric $\mathrm{CO}_{2}$ from NOAA polar satellites: the tropical zone, J. Geophys. Res., 108, 4581, doi:10.1029/2003JD003439, 2003a.

Chédin, A., Saunders, R., Hollingsworth, A., Scott, N. A., Matricardi, M., Etcheto, J., Clerbaux, C., Armante, R., and Crevoisier, C.: The feasibility of monitoring $\mathrm{CO}_{2}$ from highresolution infrared sounders, J. Geophys. Res., 108, 4064, doi:10.1029/2001JD001443, 2003b.

Crevoisier, C., Heilliette, S., Chédin, A., Serrar, S., Armante, R., and Scott, N. A.: Midtropospheric $\mathrm{CO}_{2}$ concentration retrieval from AIRS observations in the tropics, Geophys. Res. Lett., 31, L17106, doi:10.1029/2004GL020141, 2004.

Crevoisier, C. Chédin, A., Scott, N. A., Matsueda, H., Machida, T., and Armante, R.: First year of upper tropospheric integrated content of $\mathrm{CO}_{2}$ from IASI hyperspectral infrared observations, Atmos. Chem. Phys., 9, 4797-4810, doi:10.5194/acp-9-4797-2009, 2009.

Dudhia, A., Jay, V. L., and Rodgers, C. D.: Microwindow selection for high-spectral-resolution sounders, App. Opt., 41, 3665-3673, 2002.

Engel, A., Bönish, H., Brunner, D., Fischer, H., Franke, H., Gunter, G., Gurk, C., Hegglin, M., Hoor, P., Königstedt, R., Krebach, M., Maser, R., Parchatka, U., Peter, T., Schell, D., Schiller, C., Schmidt, U., Spelten, N., Szabo, T., Weers, U., Wernli, H.,
Wetter, T., and Wirth, V.: Highly resolved observations of trace gases in the lowermost stratosphere from the Spurt project: an overview, Atmos. Chem. Phys., 6, 283-301, doi:10.5194/acp-6283-2006, 2006.

Engelen, R. J. and McNally, A. P.: Estimating atmospheric $\mathrm{CO}_{2}$ from advanced infrared satellite radiances within an operational four-dimensional variational (4D-Var) data assimilation system: Results and validation, J. Geophys. Res., 110, D18305, doi:10.1029/2005JD005982, 2005.

Foucher, P. Y., Chédin, A., Dufour, G., Capelle, V., Boone, C. D., and Bernath, P.: Technical Note: Feasibility of $\mathrm{CO}_{2}$ profile retrieval from limb viewing solar occultation made by the ACE-FTS instrument, Atmos. Chem. Phys., 9, 2873-2890, doi:10.5194/acp-9-2873-2009, 2009a.

Foucher, P. Y., Détermination de profils verticaux de concentration en $\mathrm{CO}_{2}$ atmosphérique partir d'observations spatiales. Application aux donnés en occultation solaire de l'instrument ACEFTS sur SCISAT 1. PhD thesis, University Pierre et Marie Curie, Paris, 2009b.

Gelb, A.: Applied Optimal Estimation, M.I.T. Press, 180-229, 1974.

Gurney, K. R., Law, R. M., Denning, A. S., Rayner, P. J., Baker, D., Bousquet, P., Bruhwiler, L., Chen, Y. H., Ciais, P., Fan, S., Fung, I. Y., Gloor, M., Heimann, M., Higuchi, K., John, J., Maki, T., Maksyutov, S., Masarie, K., Peylin, P., Prather, M., Pak, B. C., Randerson, J., Sarmiento, J., Taguchi, S., Takahashi, T., and Yuen, C. W.: Towards robust regional estimates of $\mathrm{CO}_{2}$ sources and sinks using atmospheric transport models, Nature, 415, 626630, 2002.

Gurk, Ch., Fischer, H., Hoor, P., Lawrence, M. G., Lelieveld, J., and Wernli, H.: Airborne in-situ measurements of vertical, seasonal and latitudinal distributions of carbon dioxide over Europe, Atmos. Chem. Phys., 8, 6395-6403, doi:10.5194/acp-8-6395-2008, 2008.

Hegglin, M. I., Boone, C. D., Manney, G. L., T.G.Shephered, Walker, K. A., Bernath, P. F., Daffer, W. H., Hoor, P., and Schiller, C.: Validation of ACE-FTS satellite data in the upper troposphere/lower stratosphere (UTLS) using noncoincident measurements, Atmos. Chem. Phys., 8, 1483-1499, doi:10.5194/acp-8-1483-2008, 2008.

Hoor, P., Gurk, C., Brunner, D., Hegglin, M. I., Wernli, H., and Fischer, H.: Seasonality and extent of extratropical TST derived from in-situ CO measurements during SPURT, Atmos. Chem. Phys., 4, 1427-1442, doi:10.5194/acp-4-1427-2004, 2004.

Horowitz, L. W., Walters, S., Mauzerall, D. L., Emmons, L. K., Rasch, P. J., Granier, C., Tie, X., Lamarque, J. F., Schultz, M. G., Tyndall, G. S., Orlando, J. J., and Brasseu, G. P.: A global simulation of tropospheric ozone and related tracers: Description and evaluation of MOZART, version 2, J. Geophys. Res., 108, 4784, doi:10.1029/2002JD002853, 2003.

Jacquinet-Husson, N., Scott, N. A., Chédin, A., Crépeau, L., Armante, R., Capelle, V., Orphal, J., Coustenis, A., Boonne, C., Poulet-Crovisier, N., Barbe, A., Birk, M., Brown, L. R., CamyPeyret, C., Claveau, C., Chance, K., Christidis, N., Clerbaux, C., Coheur, P. F., Dana, V., Daumont, L., Backer-Barilly, M. R. D., Lonardo, G. D., Flaud, J. M., Goldman, A., Hamdouni, A., Hess, M., Hurley, M. D., Jacquemart, D., Kleiner, I., Kpke, P., Mandin, J. Y., Massie, S., Mikhailenko, S., Nemtchinov, V., Nikitin, A., Newnham, D., Perrin, A., Perevalov, V., Pinnock, S., 
Rgalia-Jarlot, L., Rinsland, C., Rublev, A., Schreier, F., Schult, L., Smithu, K. M., Tashkun, S. A., Teffo, J. L., Toth, R. A., Tyuterev, V. G., Auwera, J. V., Varanasi, P., and Wagner, G.: The GEISA spectroscopic database: Current and future archive for Earth and planetary atmosphere studies, J. Quant. Spectrosc. Radiat. Transfer, 100, 1043-1059, 2008.

Koner, P. K. and Drummond, J. R.: Atmospheric trace gases profile retrievals using the nonlinear regularized total least square method, J. Quant. Spectrosc. Radiat. Transfer, 109, 2045-2059, doi:10.1016/j.jqsrt.2008.02.014, 2008.

Krol, M., Houweling, S., Bregman, B., van den Broek, M., Segers, A., van Velthoven, P., Peters, W., Dentener, F., and Bergamaschi, P.: The two-way nested global chemistry-transport zoom model TM5: algorithm and applications, Atmos. Chem. Phys., 5, 417432, doi:10.5194/acp-5-417-2005, 2005.

Kulawik, S. S., Jones, D. B. A., Nassar, R., Irion, F. W., Worden, J. R., Bowman, K. W., Machida, T., Matsueda, H., Sawa, Y., Biraud, S. C., Fischer, M. L. and Jacobson, A. R.: Characterization of Tropospheric Emission Spectrometer (TES) $\mathrm{CO}_{2}$ for carbon cycle science, Atmos. Chem. Phys., 10(12), 5601-5623, doi:10.5194/acp-10-5601-2010, 2010.

Kuze, A., Suto, H., Nakajima, M., and Hamazaki, T.: Initial Onboard Performance of TANSO-FTS on GOSAT, in Fourier Transform Spectroscopy, OSA Technical Digest, Optical Society of America, 2009.

Lafferty, W. J., Solodov, A. M., Weber, A., Olson, W. B., and Hartmann, J.-M.: Infrared collision-induced absorption by $\mathrm{N}_{2}$ near $4.3 \mu \mathrm{m}$ for atmospheric applications: measurements and empirical modeling, App. Opt., 35, 5911-5917, 1996.

Levenberg, K. :A Method for the Solution of Certain Non-Linear Problems in Least Squares. The Quarterly of Applied Mathematics 2, 164-168, 1944.

Machida, T., Matsueda, H., Sawa, Y., Nakagawa, Y., Hirotani K., Kondo, N., Goto, K., Nakazawa, T., Ishikawa, K., and Ogawa T.: Worldwide measurements of atmospheric $\mathrm{CO}_{2}$ and other trace gas species using commercial airlines, J. Atmos. Oceanic Technol., 25, 1744-1754, 2008.

Matsueda, H., Taguchi, S., Inoue, H. Y., and Ishii, M.: A large impact of tropical biomass burning on $\mathrm{CO}$ and $\mathrm{CO}_{2}$ in the upper troposphere, Science China Press, 45, 116-125, 2002.

Matsueda, H., T. Machida, Y. Sawa, Y. Nakagawa, K. Hirotani, H. Ikeda, N. Kondo, and K.Goto: Evaluation of atmospheric $\mathrm{CO}_{2}$ measurements from new air sampling of JAL airliner observations, Papers in Meteorology and Geophysics, 59, 1-17, 2008.

Marquardt, D.: An Algorithm for Least-Squares Estimation of Nonlinear Parameters. SIAM J. Appl. Math., 11, 431-441, doi:10.1137/0111030, 1963.

Nakazawa, T., Miyashita, K., Aoki, S., and Tanaka, M.: Temporal and spatial variations of upper troposphere and lower stratospheric carbon dioxide, Tellus, 43B, 106-117, 1991.

Niro, F., Boulet, C., Hartmann, J.-M.: Spectra calculations in central and wing regions of $\mathrm{CO}_{2}$ IR bands between 10 and $20 \mu \mathrm{m}$. I- Model and laboratory measurements, J. Quant. Spectrosc. Radiat. Transfer, 88, 483-498, 2004.

Olsen, S. C. and Randerson, J. T.: Differences between surface and column atmospheric $\mathrm{CO}_{2}$ and implications for carbon cycle research, J. Geophys. Res., 109, D02301, doi:10.1029/2003JD003968, 2004.

Pak, B. C. and Prather, M. J.: $\mathrm{CO}_{2}$ source inversions using satellite observations of the upper troposphere, Geophys. Res. Lett., 28 , 4571-4574, 2001.

Park, J. H.: Atmospheric $\mathrm{CO}_{2}$ monitoring from space, App. Opt., 36, 2701-2712, 1997.

Patra, P. K., Maksyutov, S., Sasano, Y., Nakajima, H., Inoue, G., and Nakazawa, T.: An evaluation of $\mathrm{CO}_{2}$ observations with Solar Occultation FTS for Inclined-Orbit Satellite sensor for surface source inversion, J. Geophys. Res., 108(D24), 4759, doi:10.1029/2003JD003661, 2003.

Peters, W., Jacobson, A. R., Sweeney, C., Andrews, A. E., Conway, T. J., Masarie, K., Miller, J. B., Bruhwiler, L. M. P., Pétron, G., Hirsch, A. I., Worthy, D. E. J., van der Werf, G. R., Randerson, J. T., Wennberg, P. O., Krol, M. C., and Tans, P. P.: An atmospheric perspective on North American carbon dioxide exchange: CarbonTracker, Proc. Natl. Acad. Sci. USA, 27 November 2007, 104(48), 18925-18930, 2007.

Phillips, D. L.:A Technique for the Numerical Solution of Certain Integral Equations of the First Kind, J. Assoc. Comput. Mach., 9, 84-97, 1962.

Plumb, R.: A "tropical pipe" model of stratospheric transport, J. Geophys. Res., 301, 3957-3972, 1996.

Plumb, R. and Ko, M.: Interrelationships between mixing ratios of long-lived stratosphere constituents, J. Geophys. Res., 97, 10145-10156, 1992.

Rinsland, C. P., Chiou, L. S., Boone, C., and P. Bernath P.: Carbon dioxide retrievals from Atmospheric Chemistry Experiment solar occultation measurements, J. Geophys. Res., 115, D03105, doi:10.1029/2009JD012081, 2010.

Rodgers, C. D.: Inverse methods for atmospheric sounding. Theory and practice, World scientific, Singapore, 2000.

Sawa, Y., Machida, T. and Matsueda, H.: Seasonal variations of $\mathrm{CO}_{2}$ near the tropopause observed by commercial aircraft, J. Geophys. Res., 113, D23301, doi:10.1029/2008JD010568, 2008.

Schuck, T. J., Brenninkmeijer, C. A. M., Slemr, F., Xueref-Remy, I., and Zahn, A.: Greenhouse gas analysis of air samples collected onboard the CARIBIC passenger aircraft, Atmos. Meas. Tech., 2, 449-464, doi:10.5194/amt-2-449-2009, 2009.

Scott, N. A.: A direct method of computation of transmission function of an inhomogeneous gaseous medium : description of the method and influence of various factor, J. Quant. Spectrosc. Radiat. Transfer, 14, 691-707, 1974.

Scott, N. A. and Chédin, A.: A fast line-by-line method for atmospheric absorption computation: The Automatized Atmospheric Absorption Atlas, J.Appl.Meteorol., 20, 801-812, 1981.

Shia, R. L., Liang, M. C., Miller, C. E., and Yung, Y. L.: $\mathrm{CO}_{2}$ in the upper troposphere: Influence of stratospheretroposphere exchange, Geophys. Res. Lett., 33, L1481, doi:10.1029/2006GL026141, 2006.

Steck, T.: Methods for determining regularization for atmospheric retrieval problems, App. Opt., 41, 1788-1797, 2002.

Stohl, A., C. Forster, A. Frank, P. Seibert, and G. Wotawa, Technical Note: The Lagrangian particle dispersion model Flexpart version 6.2, Atmos. Chem. Phys. 5, 2461-2474, doi:10.5194/acp-52461-2005, 2005.

Tikhonov, A. N.: On the regularization of ill-posed problems. Dokl. Akad. Nauk SSSR, 153 49-52; MR, 28, 5577; Soviet Math Dokl., 4 (1963), 1624-1627, 1963

Twomey, S.: On the Numerical Solution of Fredholm Integral Equations of the First Kind by the Inversion of the Linear System Pro- 
duced by Quadrature, J. Assoc. Comp. Mach., 10, 97-101, 1963. von Clarmann, T. and Echle, G.: Selection of optimized microwindows for atmospheric spectroscopy, App. Opt., 37, 7661-7669, 1998.

von Clarmann, T., Glatthor, N., Grabowski, U., Hopfner, M., Kellmann, S., Kiefer, M., Linden, A., Tsidu, G. M., Milz, M., Steck, T., Stiller, G. P., Wang, D. Y., Fischer, H., Funke, B., and GilLópez-Puerta, S.: Retrieval of temperature and tangent altitude pointing from limb emission spectra recorded from space by the Michelson Interferometer for Passive Atmospheric Sounding (MIPAS), J. Geophys. Res., 108, 4736-4750, 2003. 